\title{
Connessioni su Palazzo Spada a Roma
}

\author{
Laura Farroni
}

Abstract

L'impostazione del $42^{\circ}$ Convegno Internazionale dei Docenti delle Discipline della Rappresentazione legata alle declinazioni del Connettere è occasione per presentare un quadro di connessioni rilevate in uno studio ormai avviato da alcuni anni dall'autrice del saggio.

Le possibili connessioni presenti a Palazzo Spada a Roma è il tema affrontato, connessioni che insite all'identità del fenomeno studiato, propongono approcci di investigazione diversi rispetto ad una letteratura consolidata, in quanto usano il dato acquisito dello stato di fatto (materico e dello stato dell'arte della conoscenza) come punto di partenza da cui estrapolare percorsi di approfondimento disciplinare e interdisciplinare al fine di restituire nuovi contenuti di conoscenza.

Delimitando gli studi al periodo che va dal XVI al XVII secolo fino alla morte di Bernardino Spada, possono essere messe in gioco diversi tipi di connessioni: quella delle relazioni tra saperi in contesti a scala internazionale e locale, impostata su un piano per così dire astratto; quella degli espedienti per la realizzazione delle visuali, che appartiene ad un piano percettivo che investe aspetti sensoriali e realtà fisica, che crea ambiguità di spazi, tra reale e virtuale e infine quella delle connessioni strutturali, affidata alla definizione degli elementi architettonici, in cui emerge la gestione della forma. Ricadono in questo tipo le trasformazioni morfologiche dell'impianto del palazzo da quello rinascimentale a quello barocco.

Parole chiave

Palazzo Spada, digitalizzazione, organizzazione della conoscenza, forme geometriche.
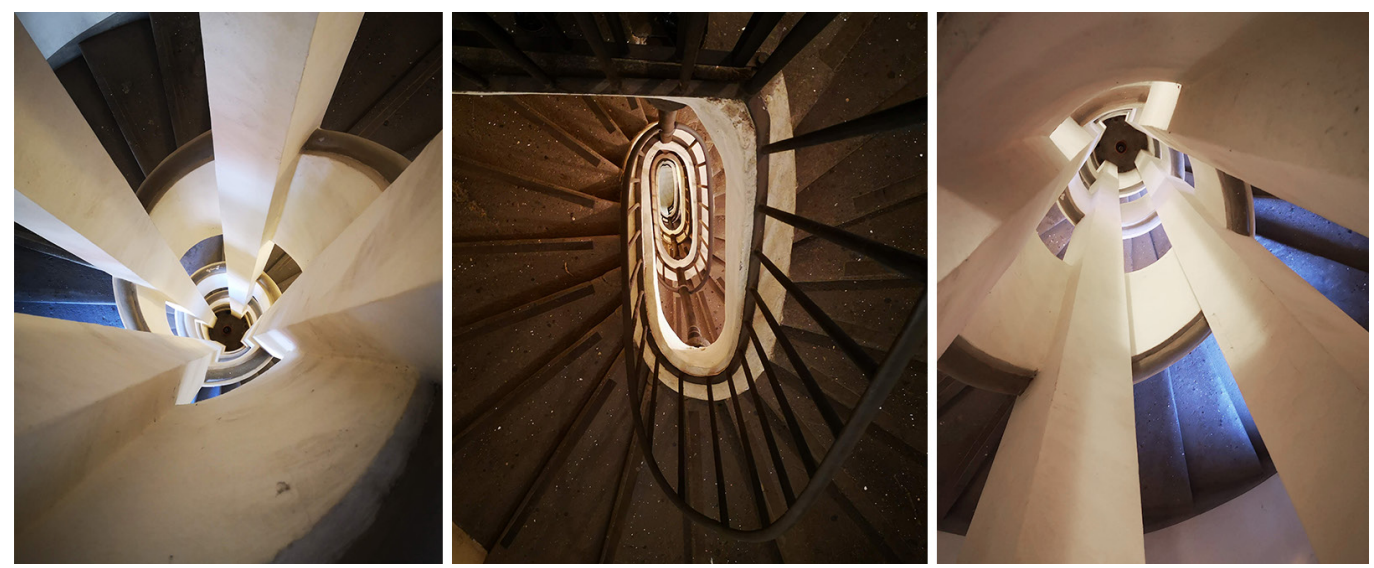
L'impostazione del $42^{\circ}$ Convegno Internazionale dei Docenti delle Discipline della Rappresentazione legata alle declinazioni del Connettere e che prende spunto, nella sua organizzazione tematica, dalle diverse figure mitologiche è occasione per presentare un quadro di connessioni rilevate in uno studio ormai avviato da alcuni anni dall'autrice del saggio.

Palazzo Spada è l'oggetto della ricerca, su cui sono avviati percorsi di approfondimento disciplinare e interdisciplinare al fine di restituire nuovi contenuti di conoscenza e/o una nuova organizzazione della conoscenza stessa.

L'approccio metodologico pone in primo piano la relazione dei saperi, attraverso un confronto effettivo tra esperti messi di fronte a dati grezzi (dove per essi s'intendono rilievi, trattati storici, documenti storici) su cui bisogna effettuare delle scelte e creare modelli specifici al fine appunto di verificare e conoscere.

Per avvallare questo approccio, si è preso anche a prestito il concetto di KOS ossia di Knowledge Organization System e in particolar modo quanto è riportato da Caudio Gnoli "L'organizzazione della conoscenza potrebbe cioè esprimere contemporaneamente diverse dimensioni: i fenomeni oggetto di studio (in questo caso Palazzo Spada con i suoi episodi figurativi e le sue trasformazioni nel tempo), le prospettive con cui vengono trattati (ambito che coinvolge appunto i saperi che indagano il fenomeno e creano modelli) e appunto i sup-

Fig. I.Vista aerea con indicati gli allineamenti. I) Fontana dell'Acqua Paola; 2)Palazzo Spada; 3 ) Palazzo Farnese: 4 Chiesa di S. Trinità dei Pellegrini:

5) Pantheon.

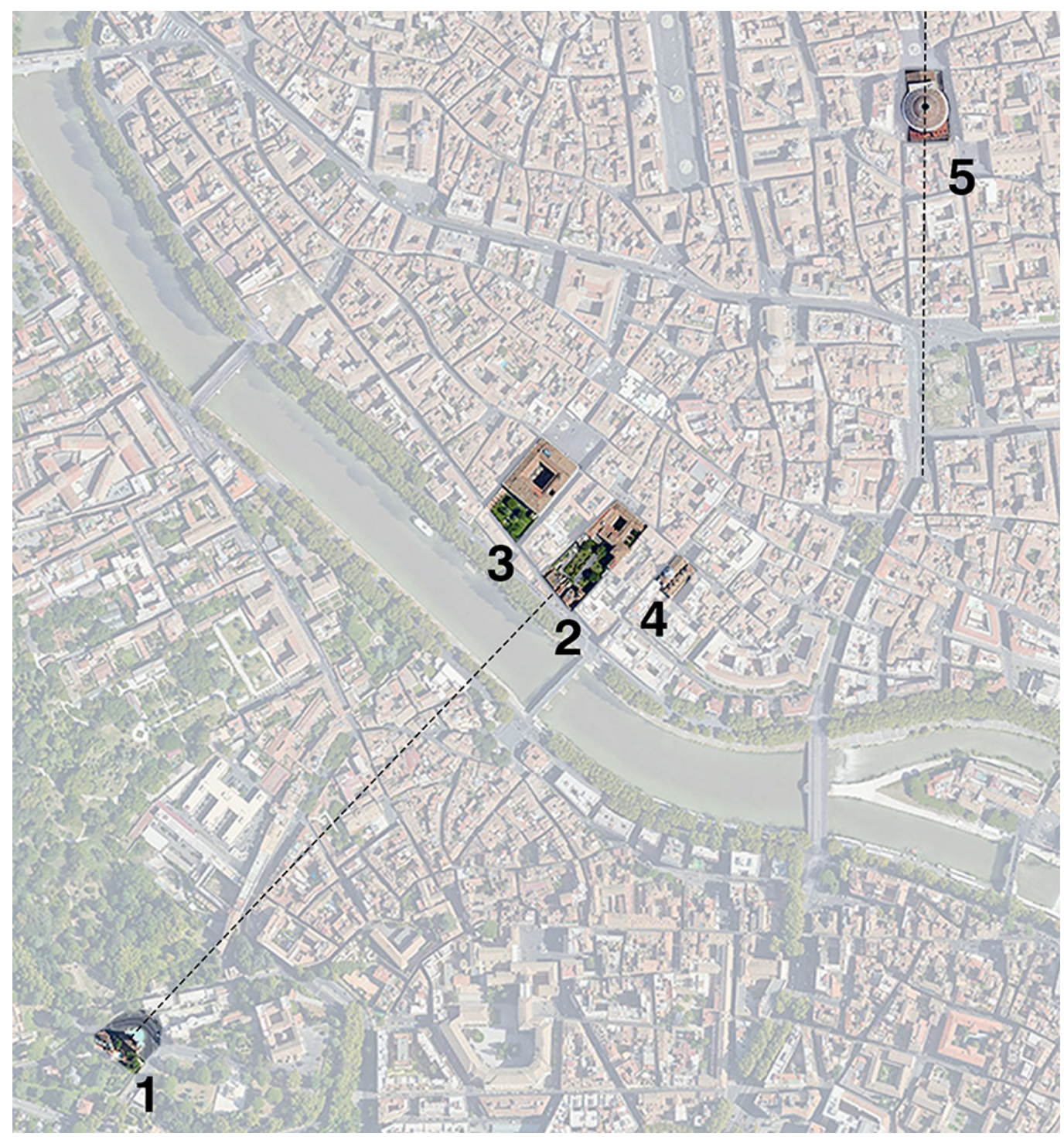


Fig. 2. Vista in pianta della nuvola di punti (work in process).

Fig. 3. Sezione $A A^{\prime}$ da Piazza Capodifero a Via Giulia. Legenda: A galleria degli stucchi; B Galleri astrolabio; C scalone d'onore; D scala a pianta circolare; E scalaa pianta ovata; F cortile centrale; G salone di Pompeo: $\mathrm{H}$ sala quattro stagion I giardino segreto; $L$ galleria prospettica; M giardini grandi; N via Giulia;

grandi; N via Giulia;
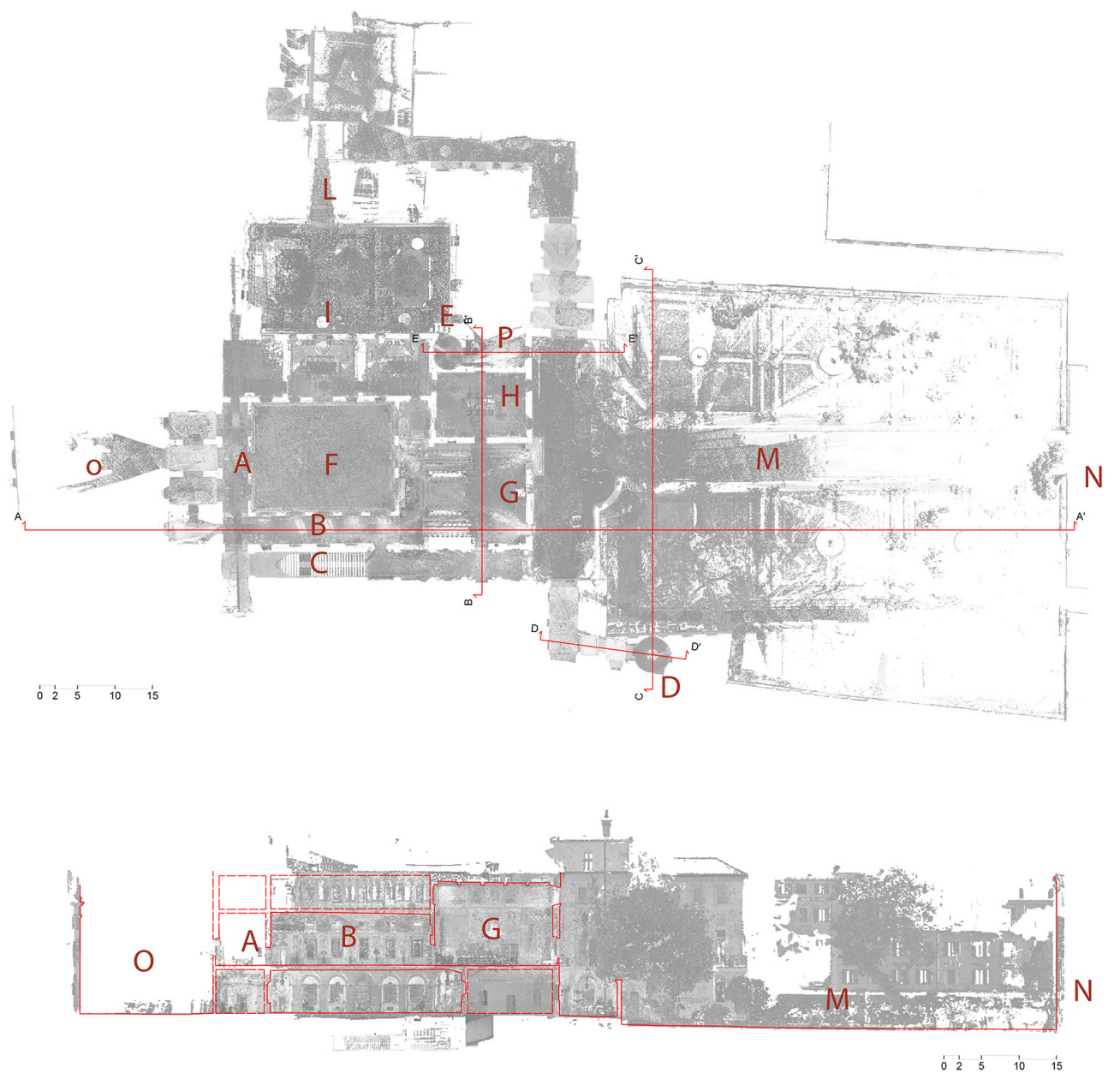

porti che ne veicolano la trattazione (ossia le modalità di uscita della conoscenza acquisita); un KOS ideale dovrebbe allora permettere di cercare separatamente la trattazione di un certo fenomeno in qualsiasi prospettiva e supporto, oppure una certa prospettiva applicata a qualsiasi fenomeno ecc." [Gnoli 20।4, p.II].

La linea, allora, che si propone è di pensare a palazzo Spada come alla confluenza di saperi teorici dell'epoca che hanno trovato la loro verifica sperimentale nella concretizzazione materica, e agli studi su di esso come una tradizione di riflessioni che nel tempo si rinnovano. Oggi, al tempo in cui è chiesto di fare un passo avanti nei modi di usare la tecnologia digitale si propone un piano neutro da cui è possibile far partire la verifica di molte riflessioni effettuate e da cui molte possono essere avviate: la digitalizzazione del fenomeno e di tutto quello che gli è pertinente. La digitalizzazione viene intesa come una sfida creativa e non una operazione statica, in grado di approcciare alla conoscenza e alla divulgazione delle opere secondo metodi critici. Si deve tenere infatti in considerazione che l'acquisizione strumentale di un'opera architettonica non è mai completamente oggettiva: si devono minimizzare gli errori nel rappresentare in un unico riferimento diverse liste di coordinate, corrispondenti a punti di presa o fotografie diversi, in un oggetto coerente e da questo avviare investigazioni, effettuando estrazione di dati a seconda dell'obiettivo prefissato.

Parlando nello specifico dell'oggetto di studio, il palazzo appunto, si ricorda che è sorto come impianto cinquecentesco per subire trasformazioni poi nel XVII secolo ad opera del Cardinale Bernardino Spada, che alla sua morte nel |66I lasciò traccia di molti episodi della cultura figurativa e scientifica del 1600, ancora apprezzabili. Alla fine del XIX secolo il palazzo divenne sede del Consiglio di Stato che lo utilizza ancora per la sua attività di giustizia 
Fig. 4. Sezione BB'

scalone/salone di Pompeo/ sala delle quattro stagioni; sezione GG' amministrativa [Cannatà 1995; Farroni 2019; Neppi 1975; Portoghesi 2020;Tabarrini 2009]. Delimitando gli studi al periodo che va dal XVI al XVII secolo fino alla morte di Bernardino Spada, si è visto che diversi sono gli ambiti artistici e scientifici che vanno a costituire la rete delle connessioni rilevabili secondo diverse tipologie: quella delle relazioni tra saperi in contesti a scala internazionale e locale, impostata su un piano per così dire astratto; quella dei saperi teorici e pratici per la realizzazione delle visuali, che appartiene ad un piano percettivo che investe aspetti sensoriali e realtà fisica. Questa connessione crea ambiguità di spazi, tra reale e virtuale e rifacendosi al topic di Meti, investe la dimensione del sapere tecnico, la sfera del divenire e del molteplice. Si ricorda che nell'interpretazione di Platone la mètis presenta quell'aspetto di abilità pratiche artigianali che può integrarsi a una conoscenza di tipo matematico [Detienne,Vernant 2005; Giorza 20 I7; Vernant 20 I4]. A palazzo Spada sembra accadere proprio questo negli episodi che riguardano l'Astrolabium Catoptrico gnomonicum di Maignan del 1644, la galleria del Borromini del I652-I653, che come nella mètis coinvolgono una intelligenza pura (nel nostro caso assimilabile a modelli teorici della sfera celeste e a regole di proporzionamento matematico). Una metamorfosi continua degli spazi, ma attentamente controllata. E infine quella delle connessioni strutturali, affidata
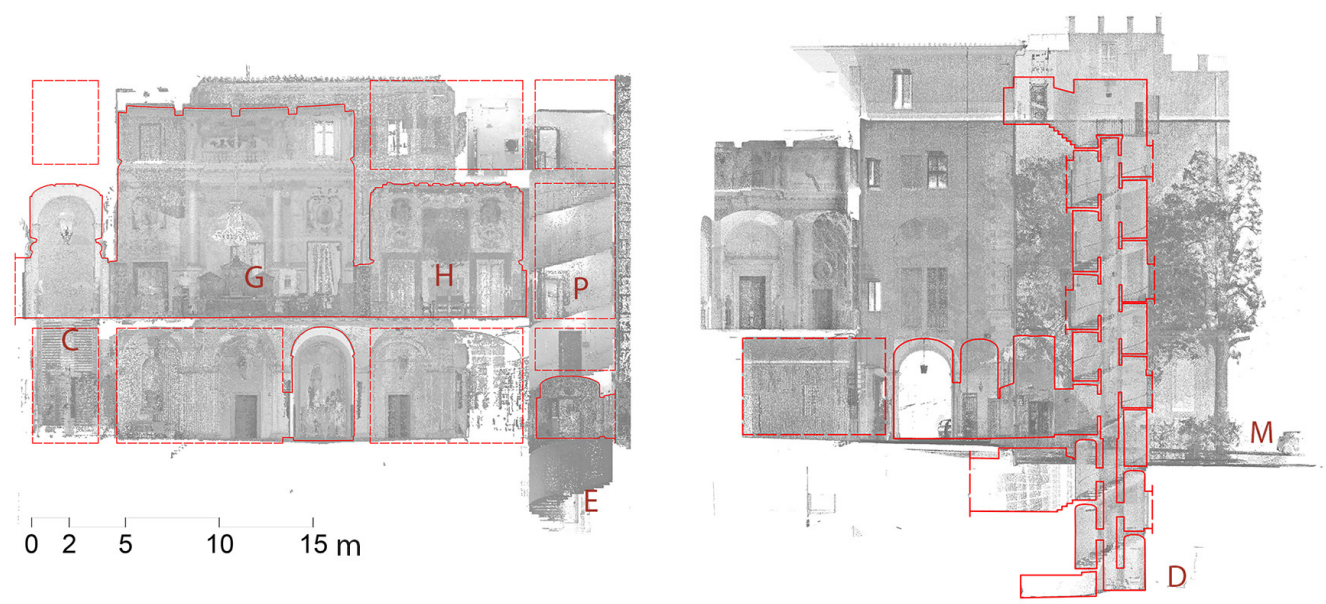

alla definizione degli elementi architettonici, che si distingue per la gestione della forma. Ricadono in questo tipo le trasformazioni morfologiche dell'impianto del palazzo da quello rinascimentale a quello barocco [Farroni 2019;Tabarrini 2009; Cannatà 1985; Neppi 1975] che esaltano il ruolo di due gallerie per i collegamenti orizzontali e lo sviluppo dei corpi scala. Le prime sono la galleria degli stucchi e dell'astrolabio entrambe al piano nobile e i secondi sono i collegamenti verticali costituiti dallo scalone d'onore e dalle scale a pianta centrale con sviluppo elicoidale (esistono naturalmente anche altri collegamenti, ma vengono considerati minori).

Quindi un primo livello di indagine connettiva è quella di tipo culturale che considera gli apporti teorici, le relazioni tra i protagonisti del dibattito scientifico e artistico dell'epoca e quindi le connessioni in grado di svelare i modelli culturali identitari europei che entrano in contatto con i saperi locali, determinando così i risultati delle singole realizzazioni intese come esito di adattamenti e compromessi. La dimensione culturale di Roma, tra XVI e XVII secolo, è in stretta relazione con quella europea e palazzo Spada è un esempio di luogo che nei secoli ha avuto rilevanza europea e locale. Bernardino Spada era protettore dell'Ordine dei Minimi del Convento di Trinità dei Monti (in contatto con Mersenne, Maignan e Niceron). Trinità dei Monti, insieme al Collegio romano dei gesuiti e all'Accademia dei Lincei, costituiva una rete culturale in collegamento appunto con il resto d'Europa. A questa 
Fig. 5. Diagramma connessioni

scalone/galleria orologio solare/galleria degli stucchi/sale/scala ovata/ sala quattro stagioni/ salone di Pompeo/scala circolare. dimensione si relazionano le volontà della committenza per l'ampliamento della residenza di famiglia, l'apporto dei numerosi architetti dell'epoca e delle capacità locali di costruire quanto si proponeva (sia la strumentazione per realizzare l'opera sia l'opera stessa).

Il secondo tipo di indagine analizza le connessioni visuali su un doppio registro, quello della relazione del palazzo con il contesto urbano e la città e quello interno alla struttura stessa. Esistono infatti connessioni visive che collegano punti caratteristici del tessuto urbano al palazzo, una tra questa è l'allineamento dell'asse longitudinale con la Fontana dell'Acqua Paola di Giovanni Fontana del |6 | |- |6 |2, materializzazione della volontà di estensione territoriale del cardinale e asse su cui impostare il disegno dei giardini, prospicenti su via Giulia, e la piazza Capodiferro. Questa connessione si allaccia agli 'abbellimenti' interni del palazzo e in particolar modo ci si riferisce alle quadrature dipinte tra cui quelle del salone di Pompeo di Mitelli e Colonna del I 635 e le visuali create dall'architetto Maruscelli (fino al I 649 anno della sua morte), rafforzate dalla costruzione dell'astrolabio ( 1644 ) che ordinerà lo spazio

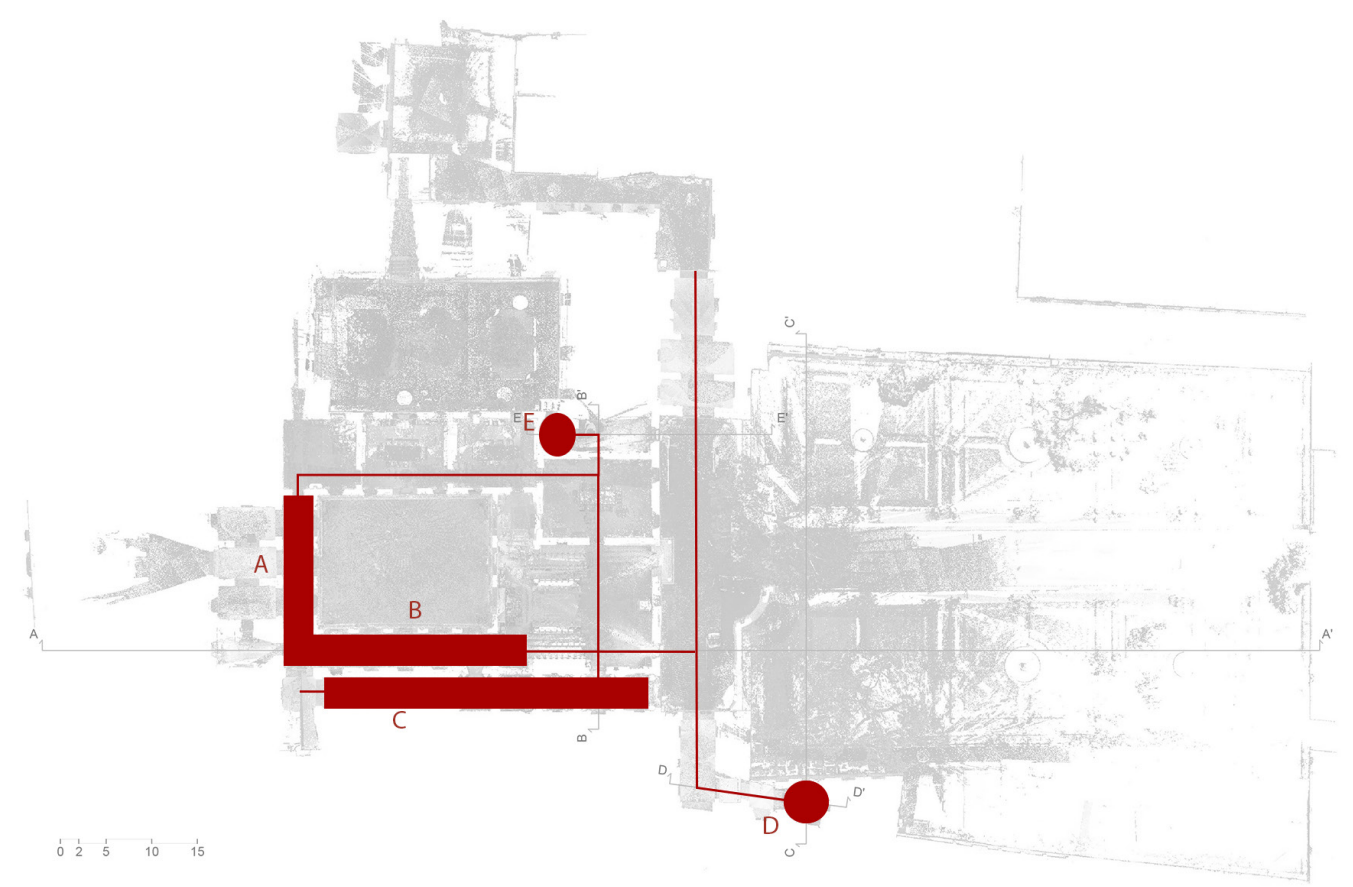

su cui si svilupperà la prospettiva del Borromini (I652-1653) [Farroni 2019]. Inoltre l'asse cittadino si rilegge nella parete sud ovest del salone di Pompeo del piano nobile, dove il camminamento o loggia dipinta si affaccia, diversamente dalle altre pareti, su uno spazio aperto, in direzione proprio della fontana detta. Uno spazio mutevole caratterizza palazzo Spada, mutevole nelle forme e ambiguo nelle configurazioni spaziali che propone.

Nel gioco delle trasformazioni acquistano importanza gli elementi/strutture che connettono gli ambienti. Le mutazioni della forma dei collegamenti verticali sono avvenute, infatti, per adeguare l'impianto cinquecentesco alle nuove esigenze funzionali della famiglia Spada. Esse rappresentano non solo l'elemento connettivo degli spazi a quota diversa, modificati in termini dimensionali, ma il luogo di incontro del sapere e del saper fare. Sono occasione di verifica tra forma, geometria e costruzione e delle possibilità innovative rispetto ad una tradizione quattrocentesca e cinquecentesca. A palazzo Spada, come detto, esistono diverse tipologie di scale. Lo scalone d'onore, di impianto rinascimentale, ma poi modificato negli anni tra il 1652 e il 1660 e le due scale a pianta centrale costruite in tempi ravvicinati. Ad oggi, non è mai stata restituita una immagine delle due scale in relazione tra di loro e questo 
Fig. 6. Galleria dell'Astrolabium Catoptrico gnomon-

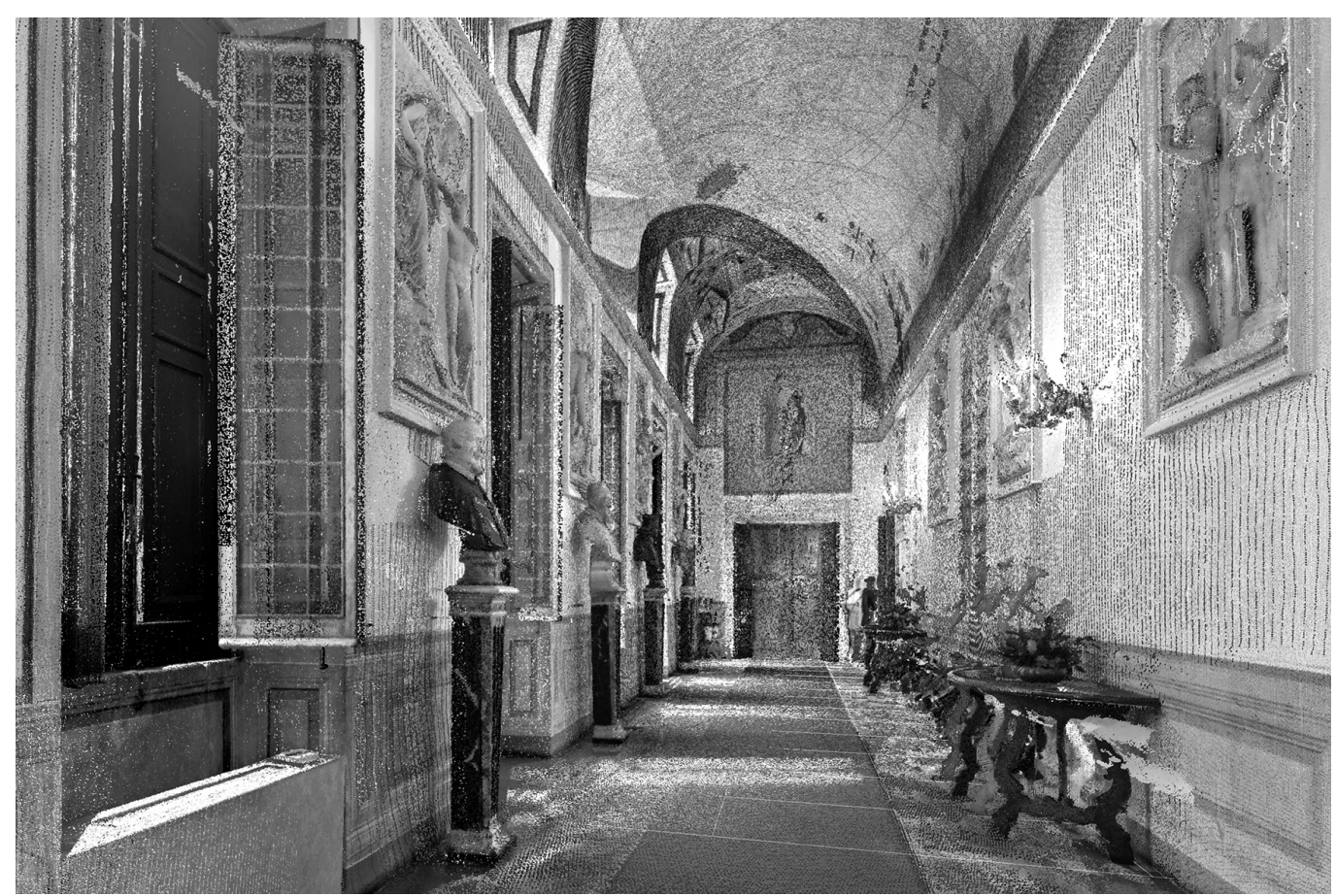

Fig. 7. Galleria degli stucchi (A), piano nobile.

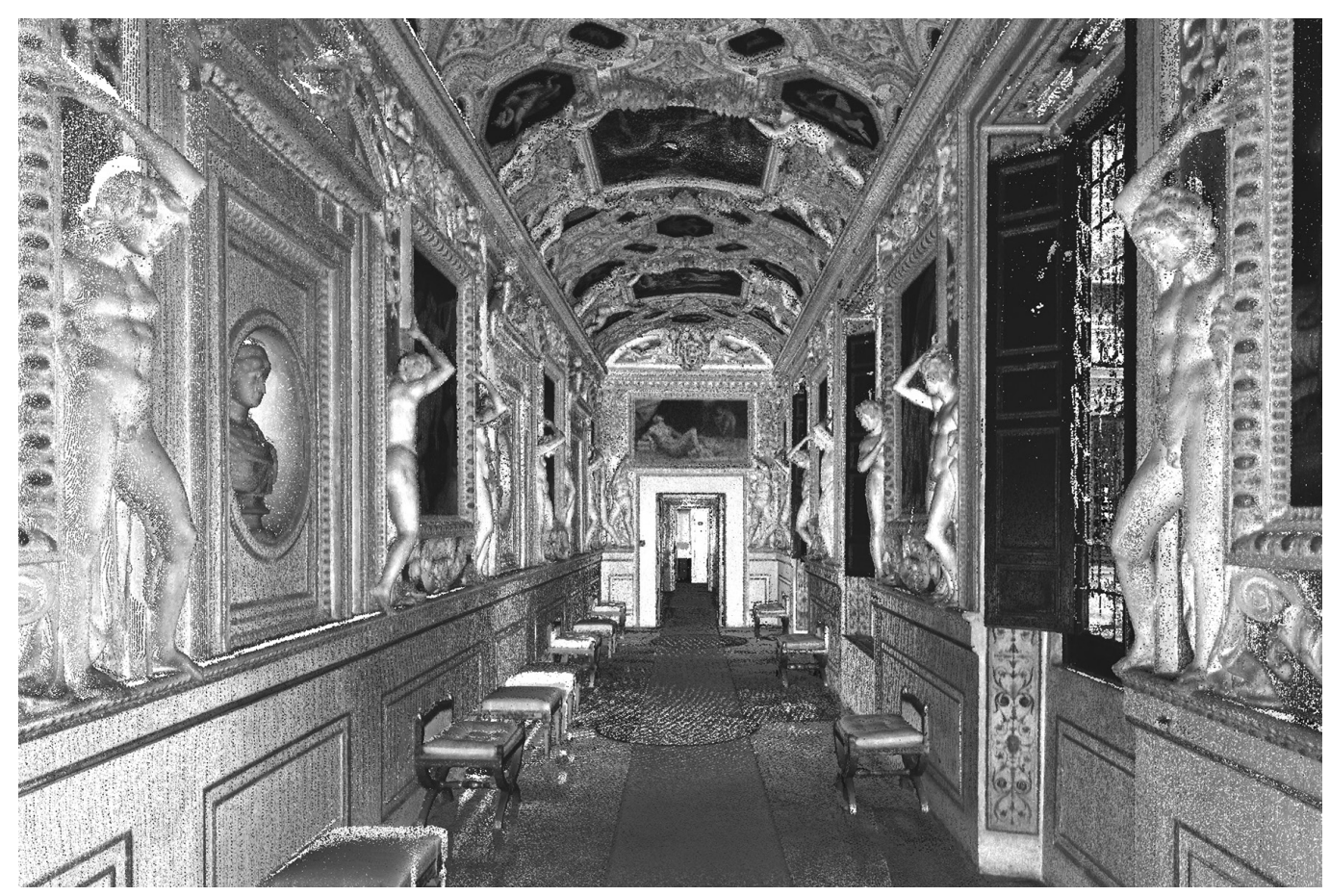


saggio propone quindi un inedito confronto che mostra le relazioni dimensionali, il posizionamento reciproco, l'andamento strutturale. Su entrambe le scale sono stati effettuati studi accurati, che evidenziano anche difficoltà e ambiguità di attribuzione e di modalità costruttive [Tabarrini 2009]. Si ricorda sinteticamente che la scala ovata nell'ala sudorientale è attribuita al Borromini e costruita contemporaneamente alla galleria solida del giardino segreto, in sostituzione di una scala a 'U' posta verso il giardino grande. La scala ovata verrà costruita in posizione più interna, e ha sempre presentato anche nel progetto attribuito al Borromini, presente all'archivio dell'Albertina, la forma ovata con nucleo centrale aperto. La scala circolare su via del Polverone è frutto di una storia più complessa, caratterizzata da progetti non realizzati del Borromini, inizialmente su forma circolare, poi ovale e poi di nuovo circolare. L'abbandono del cantiere dell'architetto nel I659, e il crollo di una prima costruzione nel |66|, hanno portato alla realizzazione di un impianto circolare elicoidale con nucleo interno svuotato che ricorda, come già menzionato da alcuni storici, la struttura della scala proposta da Egnazio Danti a 'Z', alla cui realizzazione hanno partecipato (ancora non chiaro per quanta parte) il Della Greca e il Penna. Si riporta di seguito un estratto dal testo della Tabarrini su alcuni ipotesi:" "Rosanna Di Battista scrive, avvicinandosi alla verità, che la scala circolare a lumaca prevista da Borromini su vicolo del Polverone nel primo progetto ASR, FSV, vol. 264, fol. 4 I 5 "venne sostituita da una 'ovata' che, costruita senza la guida dell'architetto ticinese, prima di essere completata, crollò per incompetenza del muratore [...];

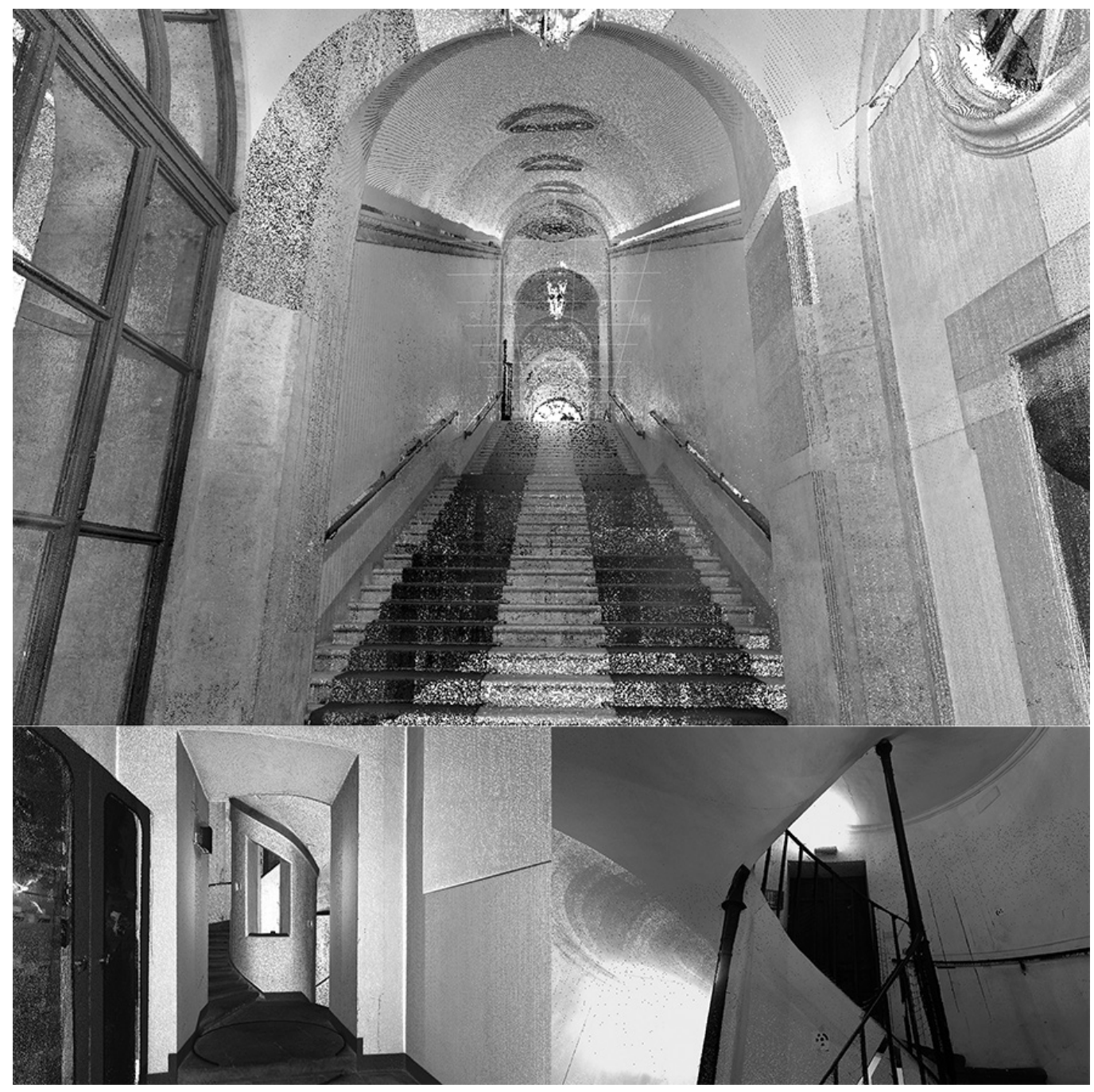



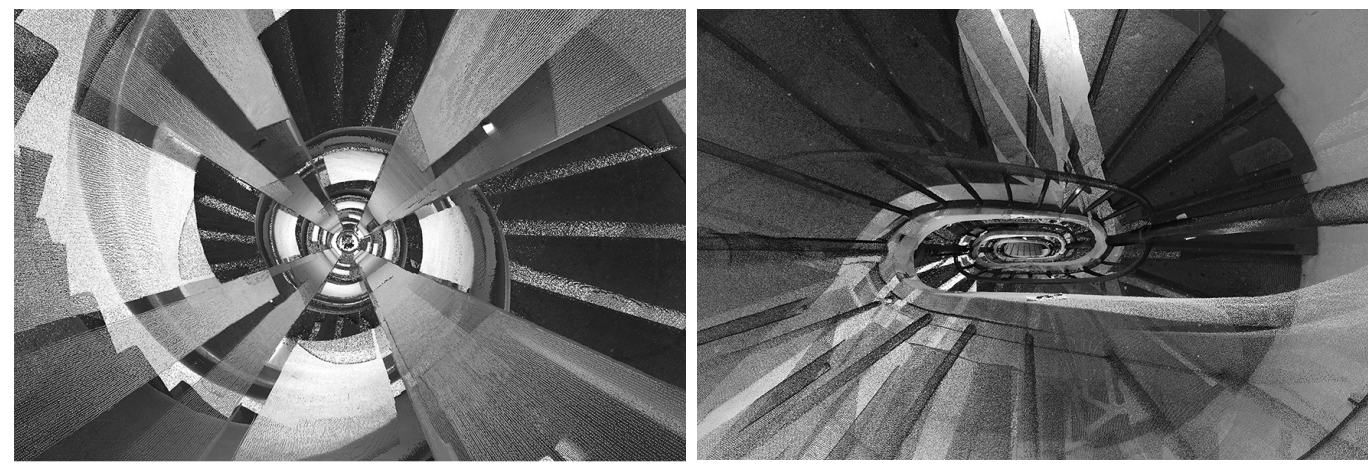

lasciando intendere che al suo posto fu poi realizzata quella circolare tuttora esistente. Una ipotesi, ancora non considerata è che, sospesa la realizzazione del progetto di ampliamento dell'ala su via del Polverone con grande scalone ovale oblungo, si ripiegasse inizialmente sulla costruzione di una scala ovata con pozzo aperto di minori dimensioni, la quale crollata nel corso della sua costruzione, venne poi sostituita da una circolare. Infatti, tra le modifiche a matita del progetto ASR, FSV, voi. 370, f. 46, si distingue il tracciato di una scala ovale minore più arretrata verso nord. Rimane il dubbio se quella definitiva, costruita con un fascio di pilastri a costituire l'anima cava centrale, debba attribuirsi ancora alla progettazione di Borromini. Nel disegno di progetto allegato al testamento di Virgilio Spada i pilastri non sono disegnati" [Tabarrini 2009, p. 53]. L'analisi dei dati di rilievo e le elaborazioni di tipo geometrico e matematico porteranno l'autore del saggio e il gruppo di ricerca (rilevatori, matematici, storici dell'architettura) a presentare risultati sulla migliore forma approssimata e sulla sua corrispondenza ad un modello ideale tenuto in considerazione all'epoca con l'intento anche di apportare nuove conoscenze sull'argomento. In questa sede non si presentano perché si parla di tipologie di connessioni e non di risultati dei modelli. Un piano di connessione, ancora, è quello simbolico. Se si amplia la visuale, espliciti sono i richiami alle macchine antiche. Le scale richiamano la macchina a turbina di Archimede, ripresa anche nel passato nella struttura della colonna traiana. Ed ancora, la presenza dell'orologio solare catottrico richiama la storia degli orologi solari, la storia degli strumenti che hanno nella sfera celeste il modello di riferimento. Ed è in questa dimensione che si rilegge un ulteriore aspetto della mètis citato da Detienne e Vernant [Detienne,Vernant 2005] essi parlano di orizzonte temporale dell'intelligenza 'flessibile'. La mètis si muove tra passato, presente e futuro. Ciò che si rilegge a palazzo Spada è frutto di capacità di gestire saperi passati, i saperi presenti come capacità di saper cogliere i modi di rendere concreto quanto la cultura andava proponendo (dall'arte alla scienza) e i saperi futuri perché in grado di rendere inesplorate ancora molte letture del fenomeno che rappresenta.

Si propone quindi il 'disegnare' (in tutte le sue declinazioni) il patrimonio costruito di riconosciuto pregio e valore come occasione per osservare di nuovo l'oggetto già studiato da molti, ma con un approccio metodologico differente permesso dalla digitalizzazione del bene e dalla creazione di modelli specifici che possono svelare collegamenti e relazioni e nuovi punti di vista. Attraverso la discretizzazione di alcuni episodi, e la creazione di modelli di studio interoperabili si possono verificare i singoli apporti disciplinari: un solo episodio owvero l'astrolabio, ad esempio, può essere legato alle trasformazioni di tutto il Palazzo, anche in relazione agli altri episodi quali le quadrature del Salone di Pompeo, la galleria del Borromini e prima ancora i dipinti del Magni e i corpi scale, e al contempo i suoi modelli specifici possono essere comparati con i possibili di altre opere simili. I modelli ne sveleranno l'aspetto qualitativo e quantitativo e secondo i principi della KOS prima citati, potranno vivere indipendenti, ma consultati secondo le diverse prospettive. Per concludere, quindi, il palazzo come una mètis si offre allo studioso, di volta in volta, regalando visioni di un organismo che comunica la sua complessa identità, mostrandosi a volte 'un tutto' e a volte per episodi, a seconda di che cosa si sceglie di conoscere. 

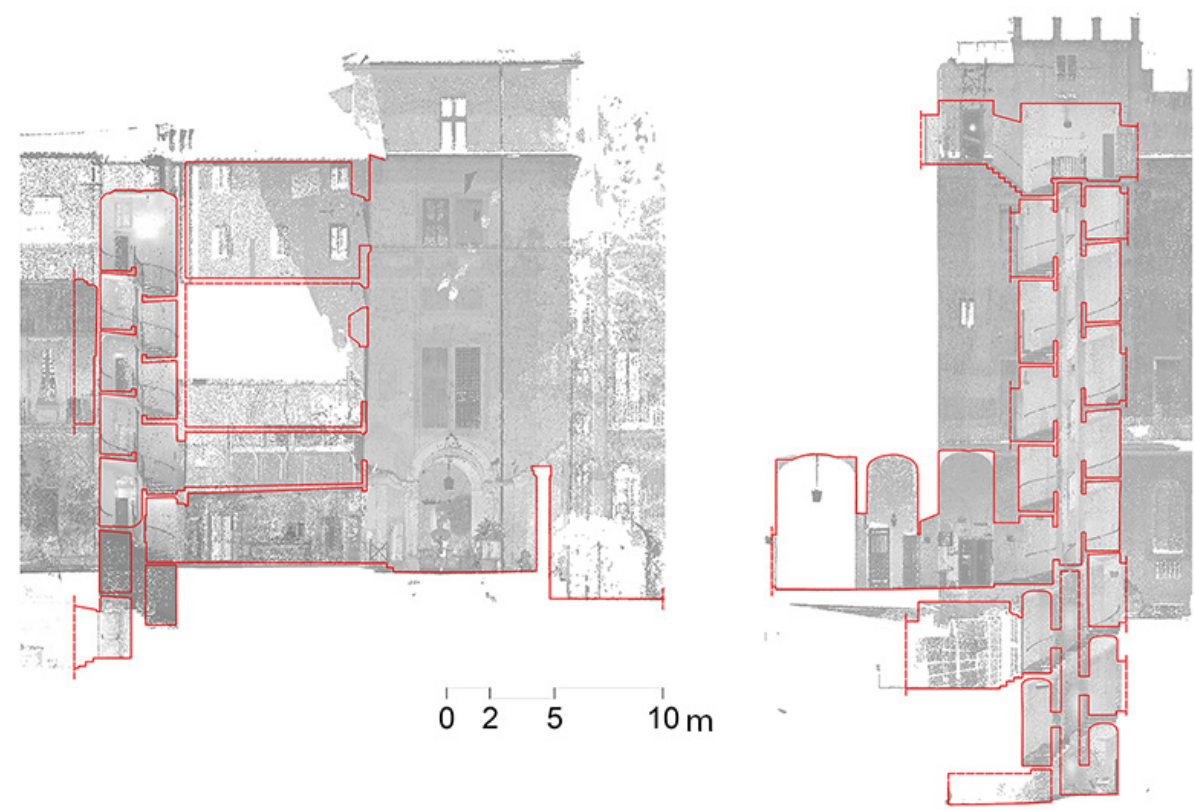

Fig. 10. Sezione sulla scala.

Fig. II. Sezione CC'.

In blu la sezione della

scala circolare interna

(non visibile in realtà in

sezione)

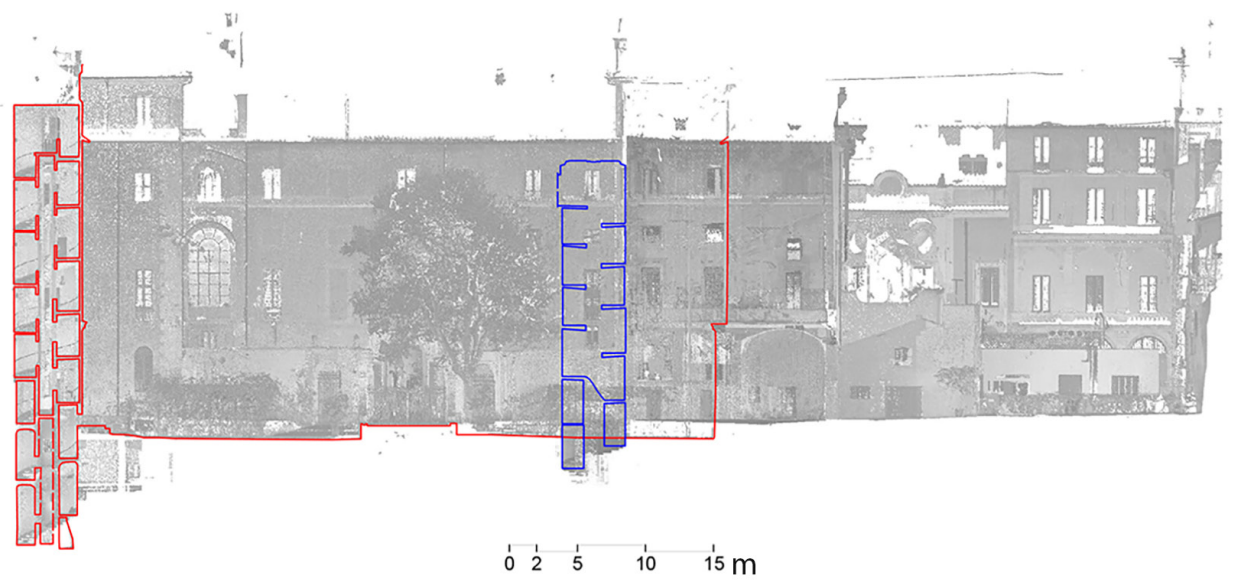



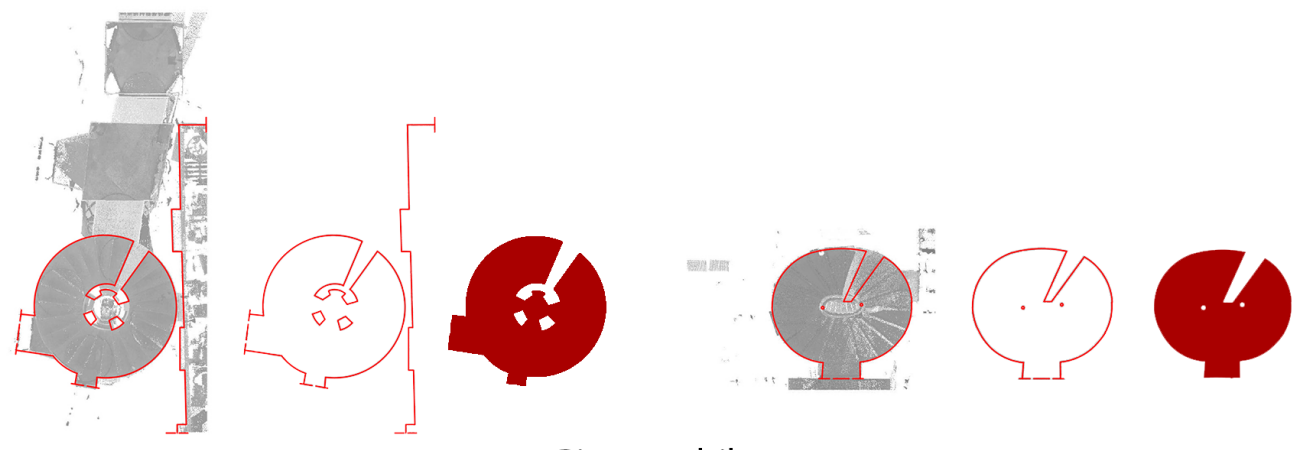

Piano nobile
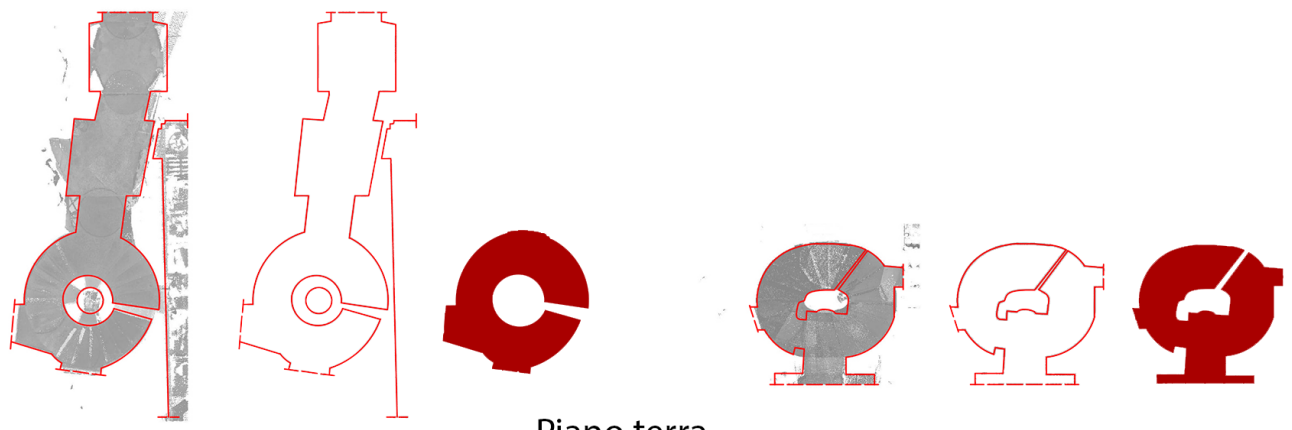

Piano terra
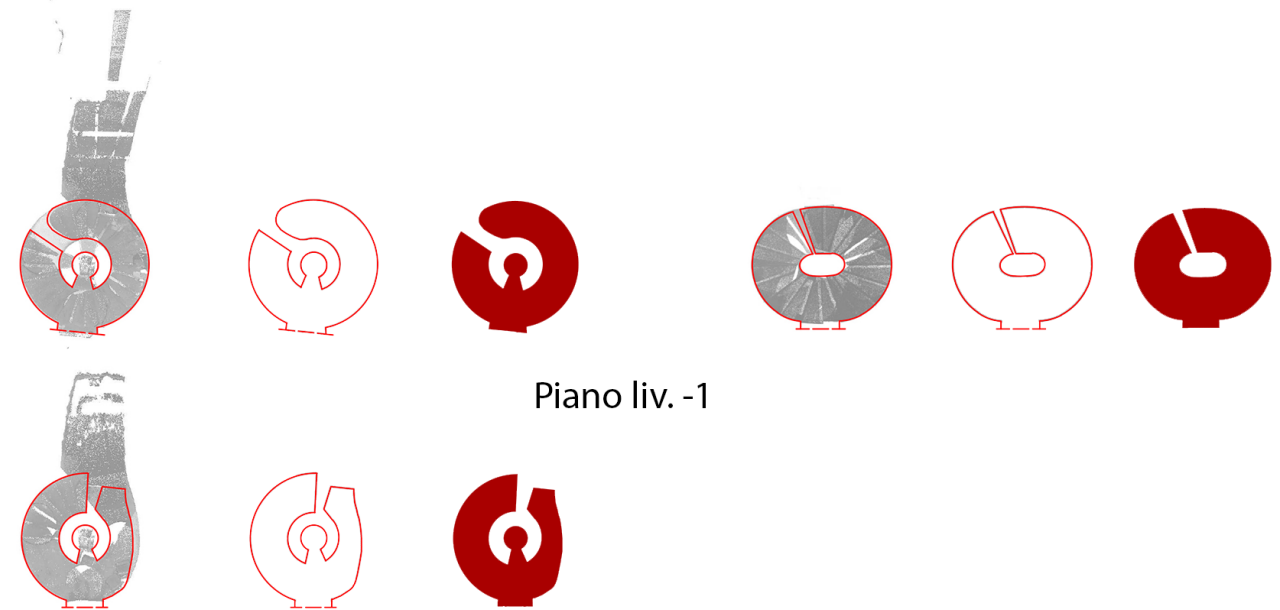

Piano liv. -1

diagrammi delle scale

pianta centrale a confron-

to (work in process).

$\begin{array}{lll}1 & 2 & 5\end{array}$

Piano liv. -2 


\section{Riferimenti bibliografici}

Cannatà Roberto (1984). Guida al Palazzo Spada. Roma: Multigrafica Editrice.

Cannatà Roberto( 1992). Palazzo Spada arte e storia. Roma: Bonsignori Editore.

De Rosa Agostino (2019). Roma anamorfica. Roma: Aracne Editrice.

Detienne Marcel, Jean Pierre (2005). Le astuzie dell'intelligenza nell'antica Grecia. Bari: Laterza. (Ed. orig. ( I99 | )Cunning intelligence in the Greek culture and Society. Chicago: University of Chicago Press.

Farroni Laura (2000). I trionfi del Barocco. Architettura in Europa I600- I 750. In Disegnare Idee e Immagini, n.20/2 I, pp. I29- I 30

Farroni Laura, Canciani Marco, Tarei Giulia (2019). L'arte del disegno e il disegno dell'arte nelle trasformazioni seicentesche di Palazzo Spada: l'Astrolabium catoptrico gnomonicum di Emmanuel Maignan. In Belardi Paolo (a cura di). Riflessioni: l'arte del disegno/il disegno dell'arte. Atti del $39^{\circ}$ Convegno Internazionale dei Docenti delle Discipline della Rappresentazione, Perugia 19-2I settembre 2019. Roma: Gangemi Editore, pp. 651-658.

Farroni Laura (2019). L'arte del disegno a Palazzo Spada. L'Astrolabium Catoptrico Gnomonicum di Emmanuel Maignan. Roma: De Luca Editori d'arte.

Giorza Elena (2017). Dalla mètis alla resilienza: proposte di sopravvivenza nel mondo del "tutto scorre". In Micro Mega, Rileggiamoli insieme: < http://temi.repubblica.it/micromega-online/dalla-metis-alla-resilienza/>.

Gnoli Claudio (20 I4). Connettere la conoscenza: quattro livelli di interoperabilità. La Biblioteca connessa. Pavia: Biblioteche oggi, pp. 8-16.

Neppi Lionello (1980). Palazzo Spada. Roma: Editalia.

Portoghesi Paolo (1966). Roma Barocca. Bari: Editori Laterza.

Portoghesi Paolo (1988). Immaginario architettonico nella pittura. Bari: Editori Laterza.

Tabarrini Marisa (2009). Borromini e gli Spada. Un palazzo e la committenza di una grande famiglia nella Roma barocca. Roma: Gangemi Editore.

Tabarrini Marisa (20 I2). Borromini, Bernini e Vincenzo Della Greca. Per l'ampliamento di palazzo Spada a Roma con il nuovo quartiere della marchesa Maria Veralli. In Rondinini Margherita (a cura di). Il mecenatismo degli Spada. Atti degli incontri di studio. Roma, Palazzo Spada, giugno 2007; Brisighella, Giardino di Villa Ginanni Fantuzzi già Spada, giugno 2008. Faenza: Carta Bianca, pp. II5-130.

Urciuoli Saverio (2017). Palazzo Spada, il percorso ritrovato. Roma: De Luca Editori d'arte.

Vernańt Jean Pierre (20|4). L'universo, gli dei, gli uomini. Torino: Einaudi. (Ed. orig. (20I4) L'Universe, les Dieux, les Hommes. Paris: Édition).

Zerlenga Ornella (2017). La scala 'vacua nel mezzo'. Due esempi napoletani a confronto I The 'empty in the middle'. A comparison of two Neapolitan examples. In di Luggo et al. (a cura di). Territori e frontiere della Rappresentazione. Atti del $39^{\circ}$ Convegno Internazionale dei Docenti delle Discipline della Rappresentazione, Napoli 14, I 5, I6 settembre 20 I7. Roma: Gangemi Editore, pp. ||6|-||68.

Autore

Laura Farroni, Università degli Studi di RomaTre, laura.farroni@uniroma3.it

Per citare questo capitolo: Farroni Laura (2020). Connessioni a Palazzo Spada a Roma/ Connections on Palazzo Spada in Rome. In Arena A., Arena M., Brandolino R.G., Colistra D., Ginex G., Mediati D., Nucifora S., Raffa P. (a cura di). Connettere. Un disegno per annodare e tessere. Atti del $42^{\circ}$ Convegno Internazionale dei Docenti delle Discipline della Rappresentazione/Connecting. Drawing for weaving relationships. Proceedings of the 42th International Conference of Representation Disciplines Teachers. Milano: FrancoAngeli, pp. I | 39- | 60. 


\title{
Connections on Palazzo Spada in Rome
}

\author{
Laura Farroni
}

Abstract

The setting of the 42nd International Conference of the Teachers of the Disciplines of the Representation linked to the variations of the Connect is an opportunity to present a framework of connections detected in a study started a few years ago by the author of the essay. The possible connections present at Palazzo Spada in Rome is the theme, connections that inherent to the identity of the phenomenon studied, propose different investigation approaches compared to a consolidated literature, as they use the acquired factual data (material and knowledge acquired) as a starting point from which to extrapolate disciplinary and interdisciplinary in-depth studies in order to return new knowledge contents. By delimiting studies from the 16th to the 17th century until Bernardino Spada's death, different types of connections can be readed: that of the relationships between knowledge in international and local contexts, set on an abstract level; that of the expedients for the realization of the visuals, which belongs to a perceptive plane that invests sensory aspects and physical reality, which creates ambiguity of spaces, between real and virtual and finally that of structural connections, entrusted to the definition of the architectural elements, in which it emerges the management of the form. The morphological transformations of the building's system from the Renaissance to the Baroque fall into this type.

Keywords

Palazzo Spada, digitalizzazione, organizzazione della conoscenza, forme geometriche.
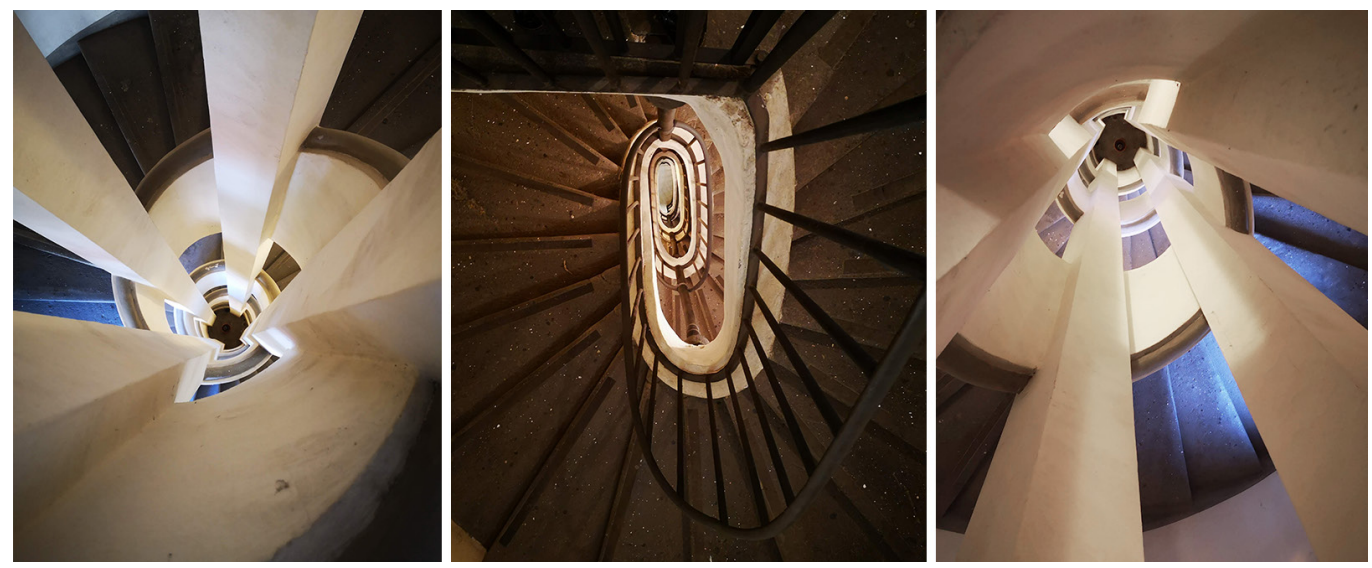
The setting of the 42nd International Conference of the Teachers of the Disciplines of the Representation is linked to the variations of the Connect and, in its thematic organization, it is inspired by several mythological figures. So, this is an opportunity to present a framework of connections about a study that is carried out by the author of the essay for some years. Palazzo Spada is the object of the research, on which disciplinary and interdisciplinary paths are set out in order to return new knowledge contents and / or a new organization of knowledge itself.

The methodological approach is focuses on the relationship of knowledge through an effective comparison of data raw (for example surveys, historical treatises, historical documents). They are analysed by different experts who have to make choices and create specific models in order to verify and know.

To endorse this approach, reference was made to the concept of KOS or Knowledge Organization System and in particular what is reported by Caudio Gnoli "L'organizzazione della conoscenza potrebbe cioè esprimere contemporaneamente diverse dimensioni: i fenomeni oggetto di studio (in this case Palazzo Spada with its figurative episodes and its transformations over time), le prospettive con cui vengono trattati (scope that involves the knowledge that investigates the phenomenon and creates models) e appunto i supporti che

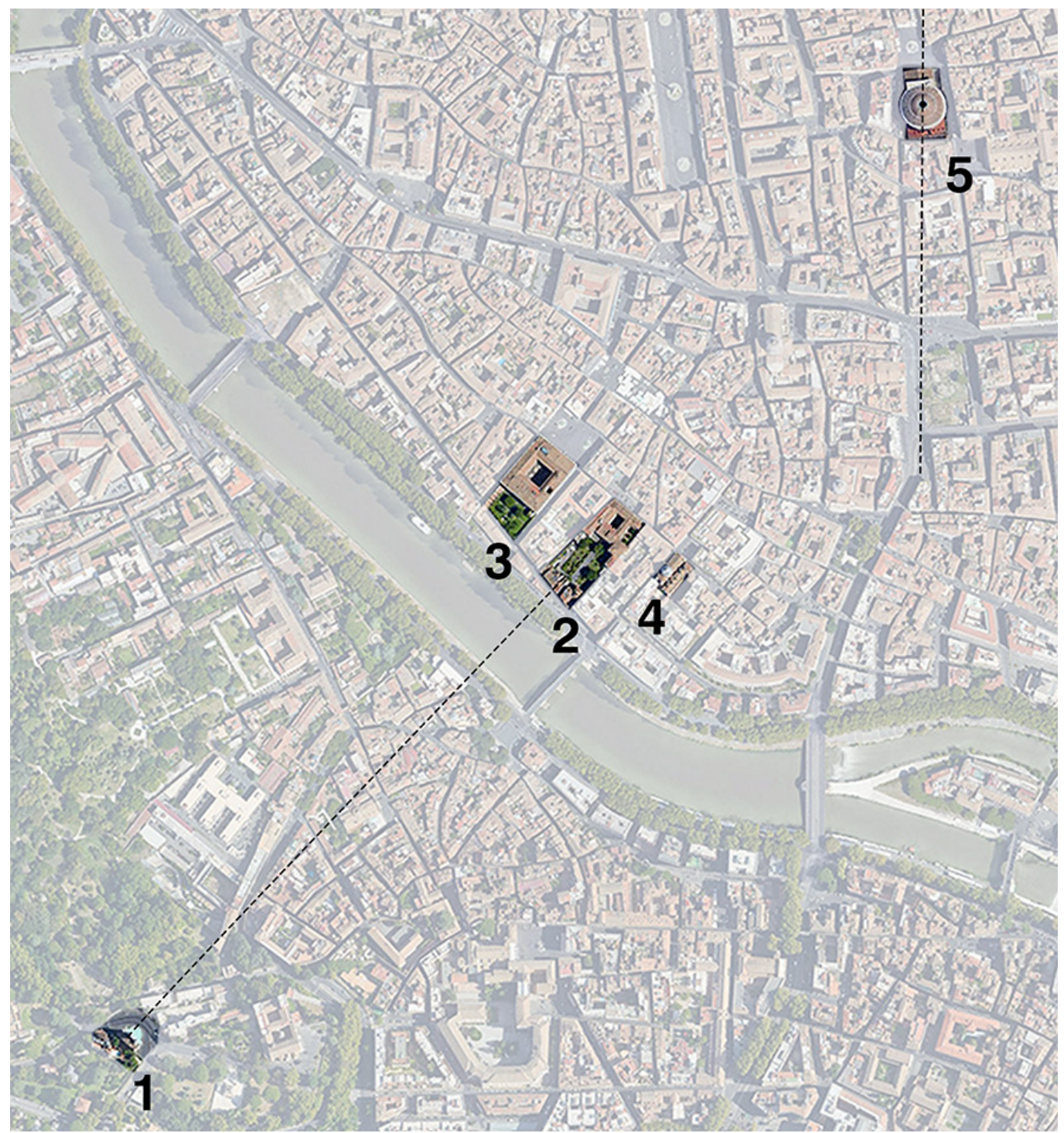


Fig. 2. Plan view of the point cloud (work in process).

Fig. 3. Section AA' from Piazza Capodifero to Via Giulia. Legenda: A. Gallery of stuccos; B. Gallery of astrolabe; $C$ Grand staircase;

D. the central plan stairs; E. E. Ovate staircase, F.centra courtyard, G. Room of Quattro Stagioni; I. Secret garden; L. Perspective Gallery; M. Large gardens; N.Via Giulia, O. Piazza Capodiferro.
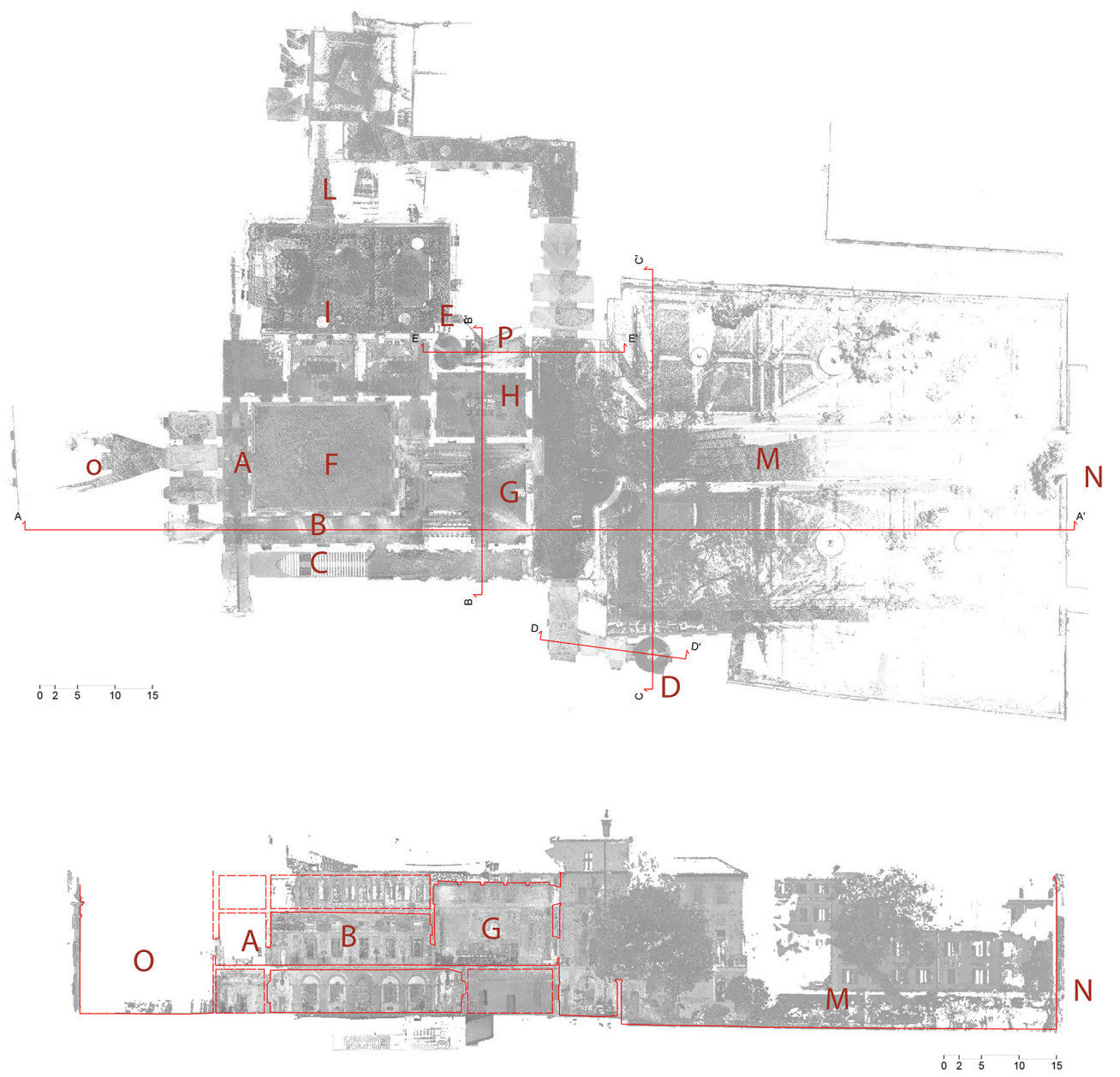

ne veicolano la trattazione (that is, the ways in which the acquired knowledge is shown); un KOS ideale dovrebbe allora permettere di cercare separatamente la trattazione di un certo fenomeno in qualsiasi prospettiva e supporto, oppure una certa prospettiva applicata a qualsiasi fenomeno ecc." [Gnoli 20 I4, p.I I].

So, the line that is proposed is to think of Palazzo Spada as the confluence of theoretical knowledge of the past. These have found their experimental verification in the material realization and, the studies on it, are to be understood as a tradition of reflections that are renewed over time.

Nowadays, at the time when asked to take a step forward in the ways of using digital technology, a neutral plan is proposed. From this it is possible to start the verification of many reflections and to start new ones: the digitization of the phenomenon and all that is relevant to it. Digitization is understood as a creative challenge and not as a static operation; it is capable of approaching the knowledge and dissemination of works according to critical methods. In fact, it must be taken into account that the instrumental acquisition of an architectural work is never completely objective: errors must be minimized through representation. This is possible by inserting different lists of coordinates (which correspond to different survey points or photographs) in a single object, coherent and belonging to a single reference system. Investigations can then be initiated from this object, by extracting data according to the set objective. Speaking specifically about the object of study, the building was built in Sixteenth Century and it undergoes transformations in the Seventeenth Century by Cardinal Bernardino Spada. When he died, he left traces of many episodes of the figurative and scientific culture of the 1600s, still appreciable. At the end of the 19th Century, 
Fig. 4. Section BB' Grand staircase/ Room of Pompeo / Room of Quattro Stagioni; section GG' the building became the seat of the Council of State, which still uses it for its administrative justice activity [Cannatà 1995; Farroni 2019; Neppi 1975; Portoghesi 2020; Tabarrini 2009]. Circumscribing the analysis from the 16th to the 17th century, until Bernardino Spada's death, there are many artistic and scientific areas united by a network of connections. These are of different types: that of the relationships between knowledge, in international and local contexts, set on an abstract level; that of theoretical and practical knowledge for the realization of the visuals, belonging to a perceptive plane of sensory aspects and physical reality. This connection creates ambiguity of spaces, between real and virtual and, referring to the topic of Meti, it invests the dimension of technical knowledge, the sphere of becoming and the multiple. Remember that in Plato's interpretation the mètis presents that aspect of artisan practical skills that can be integrated with a mathematical knowledge [Detienne,Vernant 2005; Giorza 20 I7; Vernant 20 I4]. At Palazzo Spada this seems to happen in the context of the Astrolabium Catoptrico gnomonicum by Maignan ( 644 ) and in that of the Borromini gallery (1652-1653), which as in the mètis involve a pure intelligence (in our case comparable to theoretical models of the celestial sphere and rules of mathematical proportioning rules). There is both a continuous, but carefully, controlled metamorphosis of the spaces and a
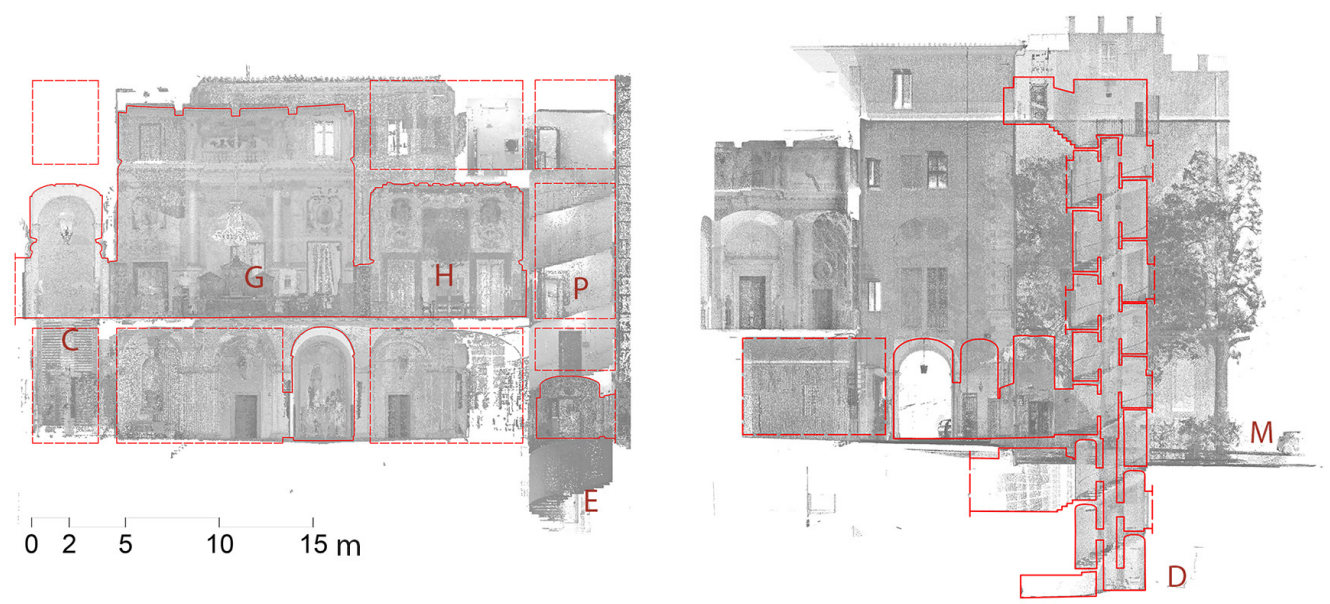

structural connection, entrusted to the definition of the architectural elements, which stands out for the management of the form. The morphological transformations of the building's system are part of this type -the Renaissance and the Baroque ones- [Farroni 2019; Tabarrini 2009; Cannatà 1985; Neppi 1975], enhancing the role of two galleries for horizontal connections and the development of staircases. The first are the gallery of stuccos and the astrolabe, both on the main floor, and the second are the vertical connections, consisting of the grand staircase and the central plan stairs with helical development (other connections naturally exist, but they are considered minor).

So, a first level of connective investigation is the cultural one, which considers the theoretical contributions and relations between the protagonists of the scientific and artistic debate of the time. These connections are able to reveal the European identity cultural models that come into contact with local knowledge and determine the results of the individual achievements, that is, the outcome of adaptations and compromises. Between the Sixteenth and Seventeenth Centuries, the cultural dimension of Rome is closely related to the European one, and Palazzo Spada is an example of a place that has had European and local relevance over the centuries. Bernardino Spada was protector of the Order of Minims of the Convent of Trinità dei Monti (in contact with Mersenne, Maignan and Niceron). Trinità dei Monti, together with the Roman Jesuit College and the Accademia dei Lincei, constituted a cultural 
Fig. 5. Diagram of connections: Grand staircase / Gallery of astrolabe / Gallery of stuccos /rooms/ ovate staircase / Room of Quattro Stagioni / Room of Pompeo / circular staircase. network in connection with the rest of Europe. Three factors were added to the cultural dimension: the will of the client for the expansion of the family residence, the contribution of the numerous architects of the time and the local ability to build what was proposed (regarding both the instrumentation to carry out the work and the work itself). The second level of investigation analyses the visual connections in a double register, that of the relationship of the building with the urban context and the city and that inside the structure itself. In fact, there are visual connections that link characteristic points of the urban fabric to the building. One of these is the alignment of the longitudinal axis with the Fountain of the Acqua Paola by Giovanni Fontana (16 | |-16|2). This is the materialization of the cardinal's desire for territorial extension and it constitutes an axis on which the design of the gardens, overlooking Via Giulia, and Piazza Capodiferro, can be set. This connection is linked to the internal 'embellishments' of the building. In particular, reference is made to the painted squares, for example the Pompeo salon, by Mitelli and Colonna ( 1635) and the views created by

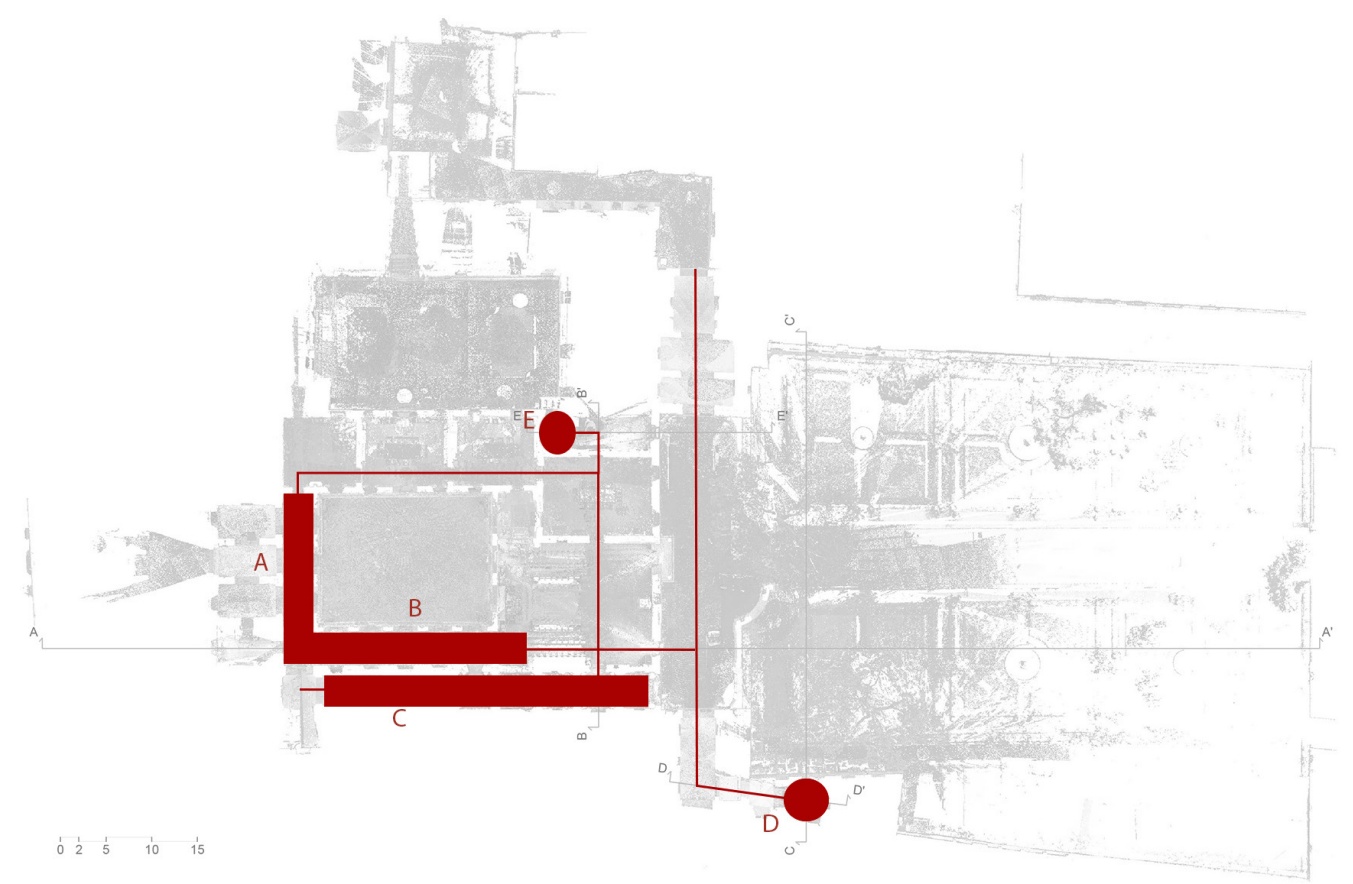

the architect Maruscelli (until 1649 the year of his death). These are emphasized by the construction of the astrolabe (1644) and it orders the space on which Borromini's perspective will develop (1652-1653) [Farroni 2019]. Furthermore, the city axis is reinterpreted in the southwest wall of Pompeo's salon on the main floor. Here, unlike the other walls, the walkway, or painted loggia, overlooks an open space in the direction of the fountain itself. Palazzo Spada is characterized by a changing space, changing in shape and ambiguous in the spatial configurations it offers.

In the game of transformations, the elements/structures that connect the rooms acquire importance. In fact, to adapt the Sixteenth Century layout to the new functional needs of the Spada family, changes in the shape of the vertical connections took place. They represent not only the connective element of spaces at different heights, modified in terms of size, but they represent also the meeting place of knowledge and know-how. They are an opportunity to verify the shape, geometry and construction and innovative possibilities compared to a Fifteenth and Sixteenth Century tradition. At Palazzo Spada, as mentioned, there are different types of stairs. The grand staircase, built in the Renaissance style, but then modified 
Fig. 6. Strolabium Catoptri(B), main floor.
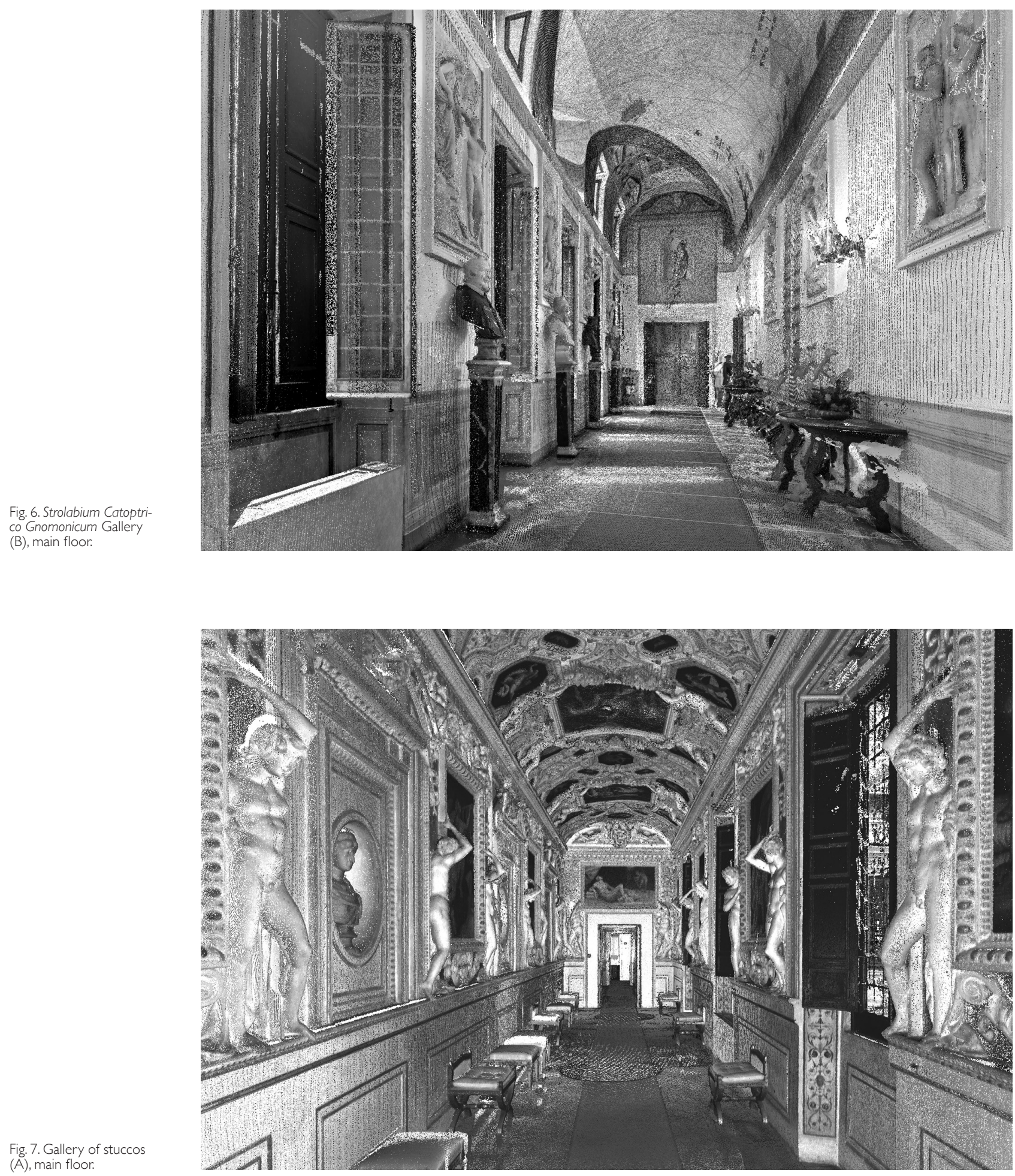
in the years between 1652 and 1660, and the two central plan staircases built in close times. To date, an image of the two scales in relation to each other has never been returned, therefore this essay proposes an unprecedented comparison, that shows the dimensional relationships, the mutual positioning and the structural trend. Accurate studies were carried out on both scales, which also highlight difficulties and ambiguities in attribution and construction methods [Tabarrini 2009]. In summary, the oval staircase in the south-east wing is attributed to Borromini and it was built at the same time as the solid gallery of the secret garden, replacing a ' $U$ ' staircase placed towards the large garden. The ovate Giulia case was built in an internal position, and has always also presented the ovate shape with an open central core in the project attributed to Borromini, present in the Albertina archive. The circular staircase on Via del Polverone is the result of a more complex history, characterized by unrealized projects by Borromini, initially on a circular shape, then oval and then again circular. The abandonment of the architect's construction site in 1659, and the collapse of a first construction in $|66|$, led to the creation of a circular helical system with an empty internal core. This recall, as already mentioned by some historians, the structure of the staircase proposed by Egnazio Danti in ' $Z$ ', in the construction of which Della Greca and Penna participated (it is still not clear in what proportion). Below is an extract from Tabarrini's text on some hypotheses: "Rosanna Di Battista scrive, avvicinandosi alla verità, che la scala circolare a lumaca prevista da Borromini su vicolo del Polverone nel primo progetto ASR, FSV, vol. 264, fol. 415 venne sostituita da una 'ovata' che, costruita senza la guida dell'architetto

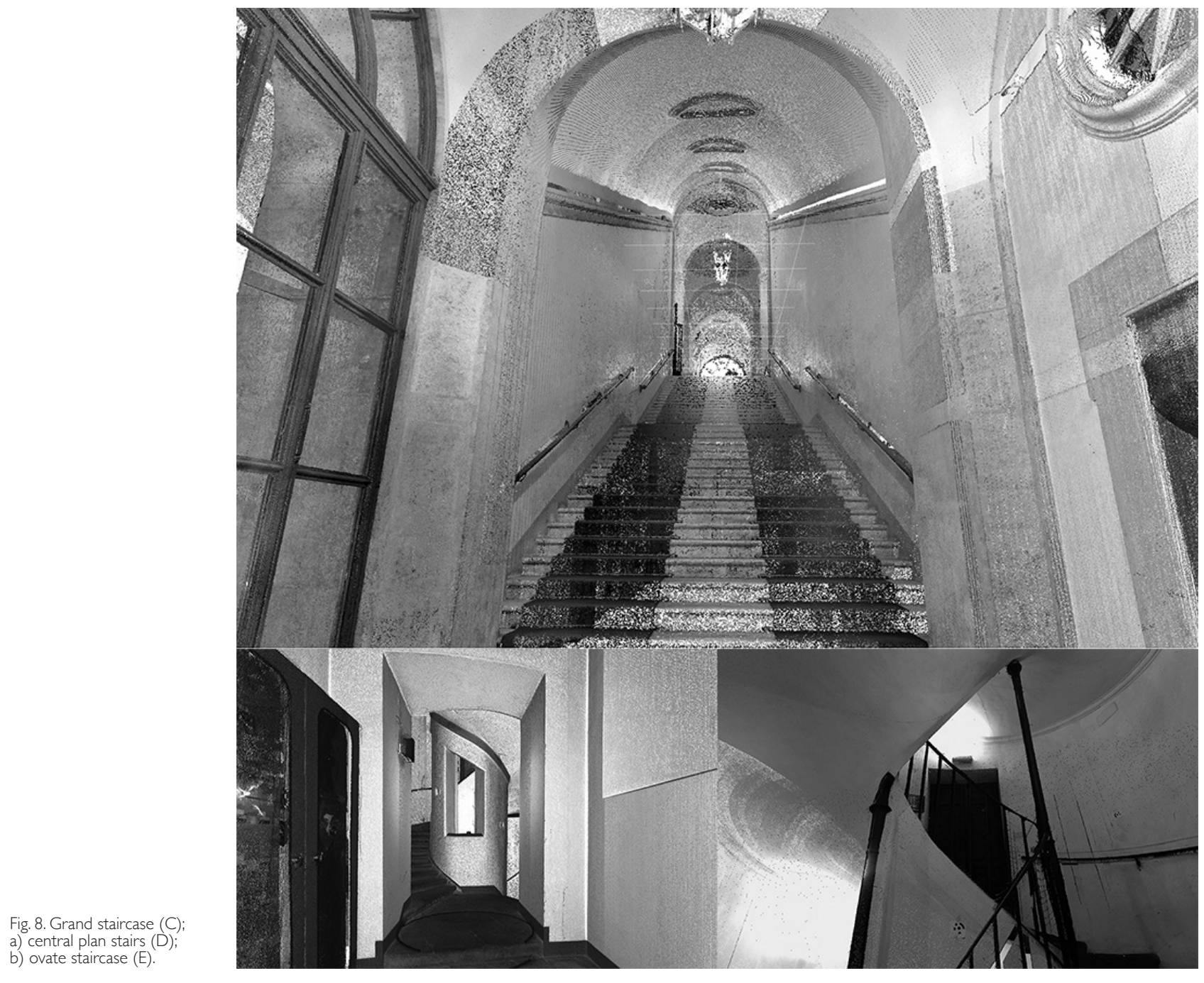


Fig. 9. a) View of helica staircase with circular plan (D); b) view of helical staircase with ovate plan (E)
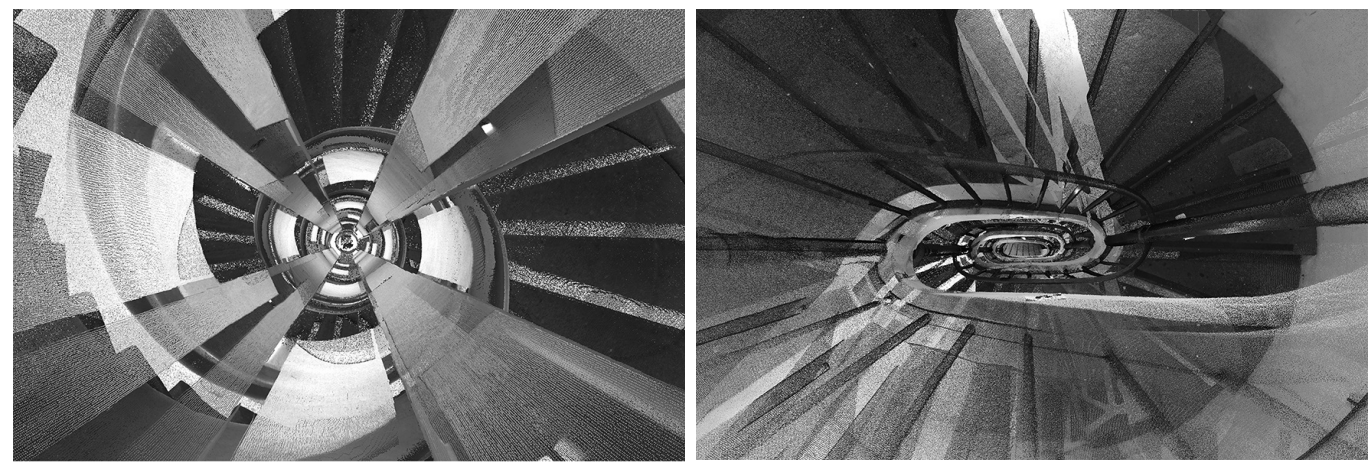

ticinese, prima di essere completata, crollò per incompetenza del muratore [...]; lasciando intendere che al suo posto fu poi realizzata quella circolare tuttora esistente. Una ipotesi, ancora non considerata è che, sospesa la realizzazione del progetto di ampliamento dell'ala su via del Polverone con grande scalone ovale oblungo, si ripiegasse inizialmente sulla costruzione di una scala ovata con pozzo aperto di minori dimensioni, la quale crollata nel corso della sua costruzione, venne poi sostituita da una circolare. Infatti, tra le modifiche a matita del progetto ASR, FSV, voi. 370, f. 46, si distingue il tracciato di una scala ovale minore più arretrata verso nord. Rimane il dubbio se quella definitiva, costruita con un fascio di pilastri a costituire l'anima cava centrale, debba attribuirsi ancora alla progettazione di Borromini. Nel disegno di progetto allegato al testamento diVirgilio Spada i pilastri non sono disegnati" [Tabarrini 2009, p. 53].The analysis of the relevant data and the geometric and mathematical processing lead the author of the essay and the research team (surveyors, mathematicians, architectural historians) to present results on two themes. These concern the best approximate form and its correspondence to an ideal model, taken into consideration at the time, which has the intention of bringing new knowledge on the subject. They are not presented here because we are talking about the types of connections and not about the results of the models. A connection plan is the symbolic one. If the view is enlarged, references to ancient machines are explicit. The stairs recall Archimedes' turbine machine, also taken up in the past in the structure of the Trajan column. And again, the presence of the catoptric sundial recalls the history of sundials, the history of the instruments that have the reference model in the celestial sphere. And it is in this dimension that a further aspect of the mètis cited by Detienne and Vernant is reinterpreted [Detienne,Vernant 2005]. They talk about the time horizon of 'flexible' intelligence. The mètis goes between past, present and future. What is reread at Palazzo Spada is the result of the ability to manage past knowledge. Knowledge is therefore present as the ability to know how to make concrete what culture was proposing (from art to science) and future knowledge are present because it can still make many readings of the phenomenon it represents unexplored.

It is therefore proposed to 'draw' (in all its forms) the built heritage, of recognized value and value, as an opportunity to observe again the object already studied by many, but with a different methodological approach. This is allowed by the digitization of the asset and by the creation of specific models that can reveal links and relationships and new points of view. Through the discretization of some episodes, and the creation of interoperable study models, individual disciplinary contributions can be verified. For example, the episode of the astrolabe can be linked to the transformations of the entire Palace, also in relation to the other episodes, such as the quadratures of the Pompeo Hall, the Borromini gallery, the Magni paintings and staircases. This means that even its specific models can be compared with those possible of other similar works. The models reveal their qualitative and quantitative aspect and according to the KOS principles mentioned above, they will be able to live independently, but consulted according to the different perspectives. To conclude, therefore, the building, as a mètis, is offered to the researcher, from time to time, giving visions of an organism that communicates its complex identity, sometimes showing itself like 'a whole' and sometimes for episodes, depending on what is chooses to know. 

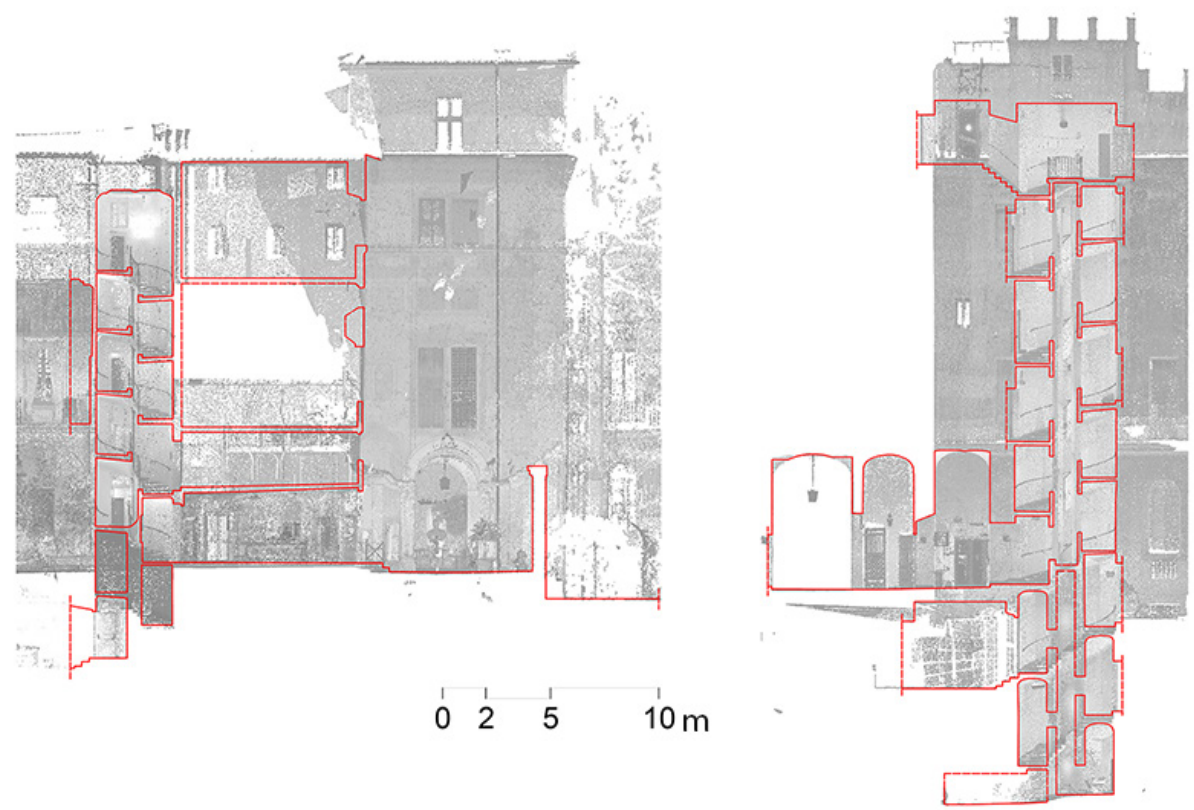

Fig. II. Section CC'

In blue the section of

circular internal staircase

(not actually visible in

section).

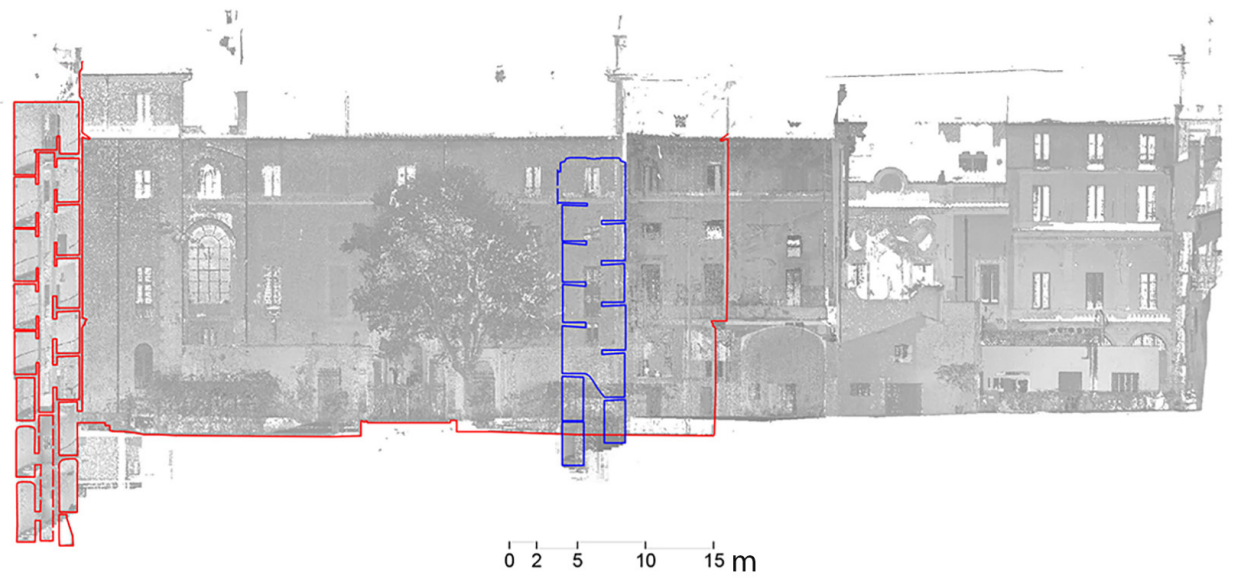



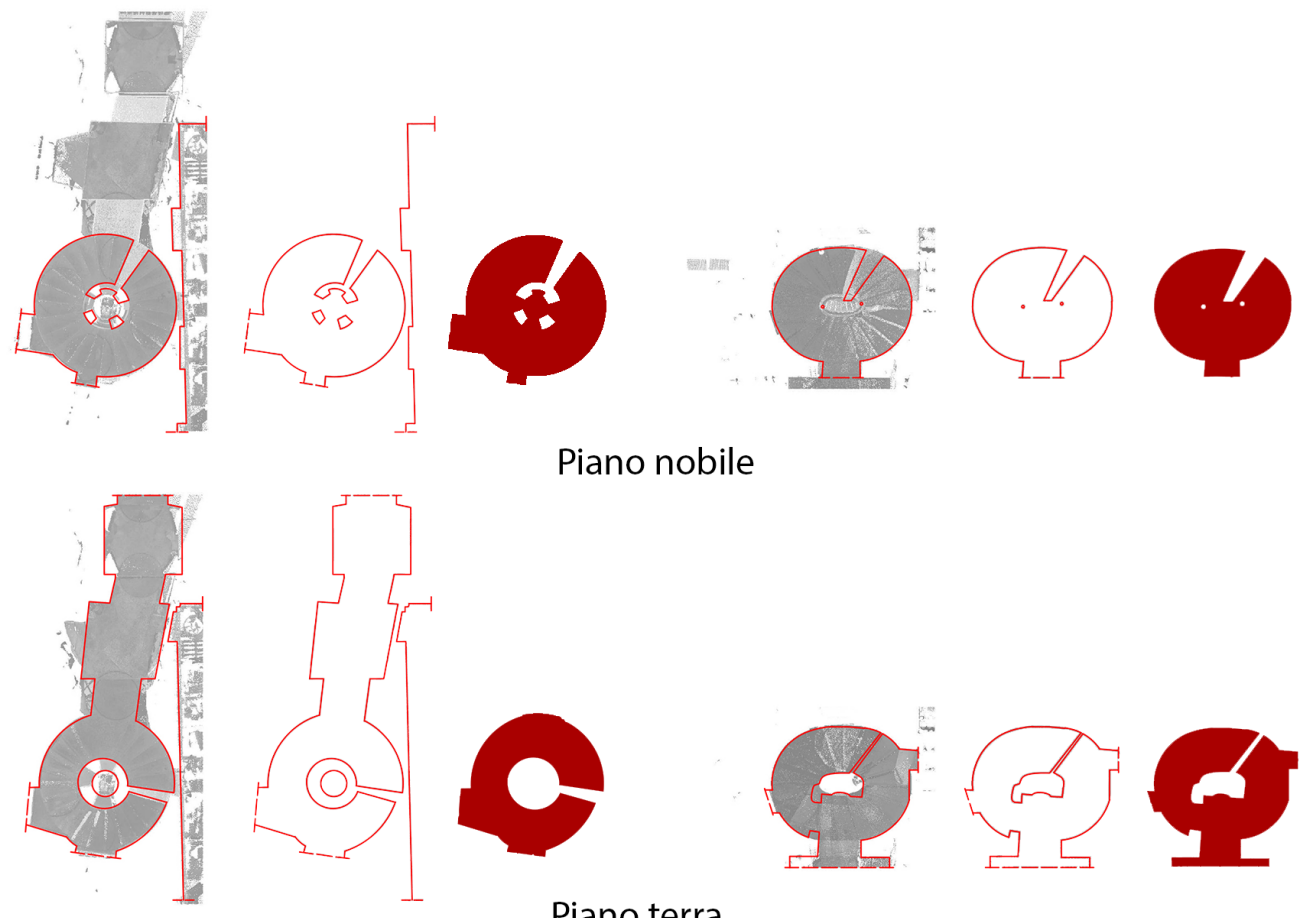

Piano nobile
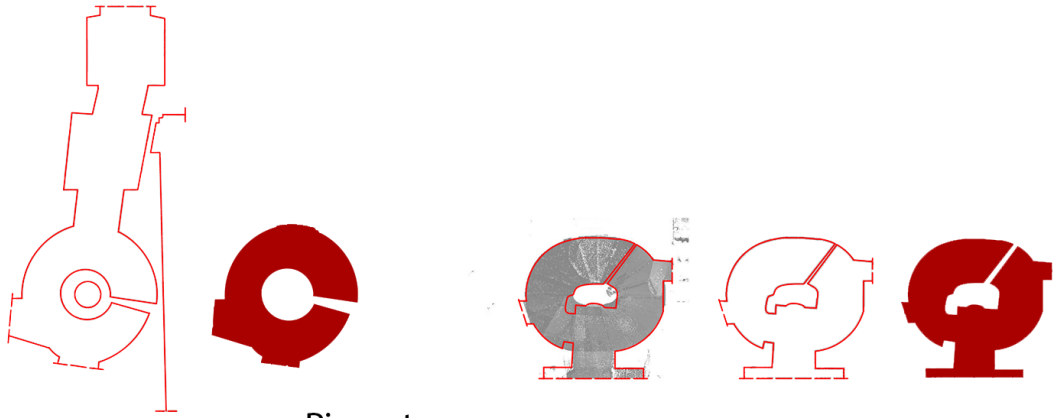

Piano terra
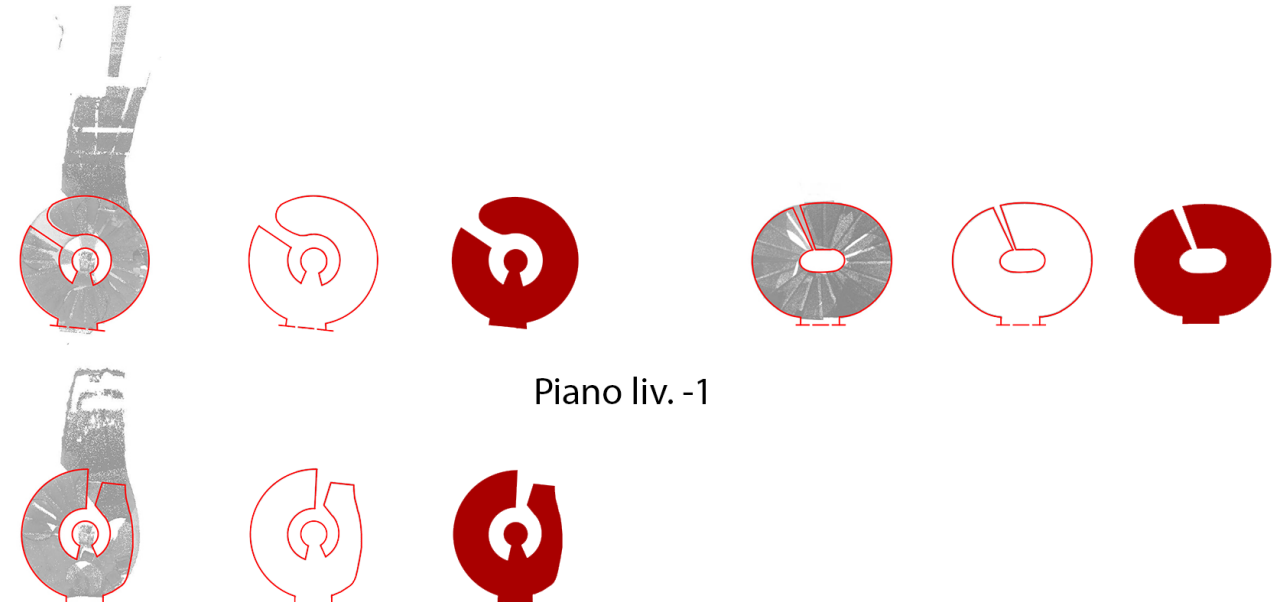

Piano liv. -1
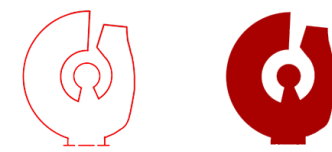

Piano liv. -2

$\begin{array}{lll}1 & 2 & 5\end{array}$ 


\section{References}

Cannatà Roberto (1984). Guida al Palazzo Spada. Roma: Multigrafica Editrice.

Cannatà Roberto( 1992). Palazzo Spada arte e storia. Roma: Bonsignori Editore.

De Rosa Agostino (2019). Roma anamorfica. Roma: Aracne Editrice.

Detienne Marcel, Jean Pierre (2005). Le astuzie dell'intelligenza nell'antica Grecia. Bari: Laterza. (Ed. orig. ( I99 | )Cunning intelligence in the Greek culture and Society. Chicago: University of Chicago Press.

Farroni Laura (2000). I trionfi del Barocco. Architettura in Europa I600- I750. In Disegnare Idee e Immagini, n.20/2 I, pp. I 29- I 30.

Farroni Laura, Canciani Marco, Tarei Giulia (2019). L'arte del disegno e il disegno dell'arte nelle trasformazioni seicentesche di Palazzo Spada: I'Astrolabium catoptrico gnomonicum di Emmanuel Maignan. In Belardi Paolo (a cura di) Riflessioni: l'arte del disegno/il disegno dell'arte. Atti del $39^{\circ}$ Convegno Internazionale dei Docenti delle Discipline della Rappresentazione, Perugia 19-2I settembre 2019. Roma: Gangemi Editore, pp. 651-658.

Farroni Laura (2019). L'arte del disegno a Palazzo Spada. L'Astrolabium Catoptrico Gnomonicum di Emmanuel Maignan. Roma: De Luca Editori d'arte.

Giorza Elena (2017). Dalla mètis alla resilienza: proposte di sopravvivenza nel mondo del "tutto scorre". In Micro Mega, Rileggiamoli insieme: < http://temi.repubblica.it/micromega-online/dalla-metis-alla-resilienza/>.

Gnoli Claudio (20 I4). Connettere la conoscenza: quattro livelli di interoperabilità. La Biblioteca connessa. Pavia: Biblioteche oggi, pp. 8-16.

Neppi Lionello ( 1980). Palazzo Spada. Roma: Editalia.

Portoghesi Paolo (1966). Roma Barocca. Bari: Editori Laterza.

Portoghesi Paolo (1988). Immaginario architettonico nella pittura. Bari: Editori Laterza.

Tabarrini Marisa (2009). Borromini e gli Spada. Un palazzo e la committenza di una grande famiglia nella Roma barocca. Roma: Gangemi Editore.

Tabarrini Marisa (20 I2). Borromini, Bernini e Vincenzo Della Greca. Per l'ampliamento di palazzo Spada a Roma con il nuovo quartiere della marchesa Maria Veralli. In Rondinini Margherita (a cura di). Il mecenatismo degli Spada. Atti degli incontri di studio. Roma, Palazzo Spada, giugno 2007; Brisighella, Giardino di Villa Ginanni Fantuzzi già Spada, giugno 2008. Faenza: Carta Bianca, pp. II5-130.

Urciuoli Saverio (2017). Palazzo Spada, il percorso ritrovato. Roma: De Luca Editori d'arte.

Vernańt Jean Pierre (20|4). L'universo, gli dei, gli uomini. Torino: Einaudi. (Ed. orig. (20I4) L'Universe, les Dieux, les Hommes. Paris: Édition).

Zerlenga Ornella (2017). La scala 'vacua nel mezzo'. Due esempi napoletani a confronto I The 'empty in the middle'. A comparison of two Neapolitan examples. In di Luggo et al. (a cura di). Territori e frontiere della Rappresentazione. Atti del $39^{\circ}$ Convegno Internazionale dei Docenti delle Discipline della Rappresentazione, Napoli 14, I 5, I6 settembre 20 I7. Roma: Gangemi Editore, pp. ||6|-1|68.

\section{Author}

Laura Farroni, Università degli Studi di RomaTre, laura.farroni@uniroma3.it

To cite this chapter. Farroni Laura (2020). Connessioni a Palazzo Spada a Roma/ Connections on Palazzo Spada in Rome. In Arena A., Arena M., Brandolino R.G., Colistra D., Ginex G., Mediati D., Nucifora S., Raffa P. (a cura di). Connettere. Un disegno per annodare e tessere. Atti del $42^{\circ}$ Convegno Internazionale dei Docenti delle Discipline della Rappresentazione/Connecting. Drawing for weaving relationships. Proceedings of the 42th International Conference of Representation Disciplines Teachers. Milano: FrancoAngeli, pp. I | 39- | 60. 